\title{
The Political Economy of Indonesia's Renewable Energy Sector and Its Fiscal Policy Gap
}

\author{
Aidy Halimanjaya ${ }^{1,2}$ \\ ${ }^{1}$ SDGs Center, Padjadjaran University, Bandung, Indonesia \\ ${ }^{2}$ Dala Institute, Jakarta, Indonesia
}

Email address:

a.halimanjaya@dala.institute

To cite this article:

Aidy Halimanjaya. The Political Economy of Indonesia's Renewable Energy Sector and Its Fiscal Policy Gap. International Journal of Economics, Finance and Management Sciences. Vol. 7, No. 2, 2019, pp. 45-64. doi: 10.11648/j.ijefm.20190702.12

Received: February 5, 2019; Accepted: March 21, 2019; Published: April 26, 2019

\begin{abstract}
This research paper identifies fiscal policy gaps that occur in Indonesia's renewable energy (RE) sector and analyses its political economy. Primary data from 37 stakeholders and secondary data from fiscal policies from Indonesia's 2007-2017 taken from Ministry of Finance (MOF) and Ministry of Energy and Mineral Resources (MEMR) regulation databases. The fiscal policy data were analysed using a cluster approach and meta-synthesis method. The results show that Indonesia has experienced multi-faceted principal-agent problems between PT PLN, the agent with sole authority to manage electricity transmissions, and various principals, namely the Ministry of State Owned Enterprises (MSOE), the MEMR, the Ministry of Industry (MOI) as the intermediary between domestic and foreign RE industries, and the MOF. While changing the MEMR's feed-in-tariff (FiT) policies sends an uncertain policy signal, the MOF's fiscal incentive policies other than FiT to promote RE development in Indonesia remain sub-optimal; the fiscal policies required to incentivise a large volume of smalland medium-scale investment in RE are absent. Differentiated tax rates and tax-break periods for national and foreign companies on the micro, small and medium scales could significantly accelerate the development of RE by both domestic and foreign companies, supporting Indonesia in achieving its sustainable development goals and emission reduction targets under its nationally determined contribution.
\end{abstract}

Keywords: Indonesia’s Fiscal Policies, Political Economy, Renewable Energy

\section{Introduction}

Indonesia is a large developing country in transition whose renewable energy (RE) sources and ambition to utilise them are immense, but progress has been slower than expected. In 2015 , the country held $40 \%$ of the world's geothermal resources but generated only 8.2 gigawatts $(\mathrm{GW})$ : less than $2 \%$ of its RE potential and less than $4.3 \%$ of RE in Indonesia's total energy mix [1]. Other energy sources namely wind and solar PV are similarly under-utilised. The development of Indonesia's RE is lagging behind its ambition to increase its contribution to its energy mix from $10-23 \%$ by 2025 and to $31 \%$ by 2050 , as stated in Presidential Regulation Number 22 Year 2017 in, the National Energy Plan (RUEN) [1].

Despite its large energy potentials and ambitions, political interests in Indonesia often hinder the creation of stable fiscal policy for RE development in the country. There is little in the RE literature that addresses both the country's political economy and its fiscal policy with regard to the RE sector [2]. The majority of RE studies discuss the problems of weak governance, the complex regulatory system, and the failure to include environmental and infrastructure issues in the development of RE projects at length [3, 4]. Roy et al. (2013) [5] point out the importance of fiscal incentives as an instrument for assisting energy transition. Political economy aspects and fiscal incentives tend to change rapidly and create uncertainty. This diverts investors from deploying large amounts of finance to scale up RE projects in Indonesia.

National and international efforts to promote RE development in Indonesia focus on the technical and policy aspects, but political support is scanty. Some government efforts, including technical guidance for RE developers considering their project-financing options $[6,7]$, a one-door 
policy to simplify investment procedures to attract large investments [8], and the enactment of Government Regulation Number 9 Year 2016 on the reduction of corporate income tax, have been developed to attract investment more broadly, including RE development. These efforts aim to help the country to achieve its RE targets by 2025, although the National Parliament is reluctant to develop RE by providing direct financial benefits to companies through feed-in-tariff (FiT) policies due to its preference to subsidise only poor people [9]. FiT can be used strategically to encourage economic activity, including by accelerating energy conservation and developing new and RE [10].

A number of international development programmes work in parallel with the Indonesian government to catalyse private investment in developing the country's RE [11]. The UK's low-carbon support for the MOF, the US's Indonesia Clean Energy Development (ICED), and the Pro-Clime Programme provide grants for the development of ministries' capacity for energy and fiscal policy. A more direct financing programme such as the US\$500 million World Bank Loan for Energy development fills the resource gap at the macro scale and at the same time promotes reducing the fossil fuel subsidy [12]. Some forms of assistance at the micro scale include providing seed funding for commercial and communitybased RE projects producing less than $10 \mathrm{MW}$ [13]. With all of this multi-front policy and technical support, the growth of Indonesia's RE still lags behind that of some other Asian countries [14].

There is very little in the literature that provide an overarching analysis of both Indonesia's political economy and its fiscal policies related to its RE sources. Some papers discuss the political economy with reference to the key RE stakeholders in Indonesia, while others address specific fiscal policies on specific energy sources. Bakhtyar et al. (2013), Dutu (2016), Fathoni et al., (2014), Nasruddin et al. (2016) and Winters and Cawvey (2015) focus on energy-pricing policies, especially for geothermal energy [3, 4, 15-17].

Some research on fiscal policies focuses heavily on FiTs, but there is little analysis of the variation of cost structure of RE projects and how fiscal policies are tailored to that in each specific country. Bakhtyar et al. (2013) [15] and Fathoni et al. (2014) [16] do not discuss other fiscal incentives such as tax breaks and value added tax (VAT) reduction, but they highlights some challenges to implement FiT in Indonesia and the Philippines.

A wide range of fiscal policies can be used to encourage economic activity, address the external costs of energy [18], and assist countries' energy transition toward a greener economy [19]. For example, government guarantees and financing facilities are considered in reducing risks, such as risk of failure in the exploration of geothermal energy.

The above research is relevant to Indonesia's energy policy, which has the potential to fall into an unsustainable trend [20]. Following global energy trends, Indonesia's energy consumption is increasing rapidly [21, 22]. Indonesia can easily fill its energy gap with coal since it has the largest coal reserve in the world [23]. Indirect fossil fuel subsidies such as government guarantees for coal power-plant development remain high [24]. Unpacking the roadblocks and providing policymakers with recommendations about accelerating the development of RE in Indonesia hopefully clarify what policy actions to be taken to contribute to the achievement of a global temperature of below 1.5 degree Celsius above preindustrial level.

In response to the lack of literature offering an overarching analysis of Indonesia's political economy regarding the development of fiscal policies related to its RE sources, this paper asks two questions: What major fiscal policy gaps in Indonesia's RE sector remain unaddressed? And 'How does the political economy of Indonesia's RE sector related to fiscal policy development?'

The paper is organised into six sections. The next section reviews academic literature that identifies challenges to Indonesia's RE development which have been overlooked. The third section explains the methodology used in this research; the fourth answers the first question and identifies the fiscal policy gap in Indonesia's RE to support the country's RE development; the fifth responds to the second question and discusses the political economy that shapes the development and the implementation of fiscal policies for RE sector in Indonesia; the last section offers concluding remarks and policy recommendations.

\section{Indonesia's Hidden Roadblocks to Renewable Energy}

The academic literature on Indonesia's RE mainly focuses on major policy and technical barriers, namely fossil fuel subsidies, the weak and complex governance set-up, and the lack of capacity in strategic areas such as human and technical resources $[3,25,26]$. Little attention is given to unpredictable political forces behind policy decisions by academic community; so far the political economy is only discussed in the case of oil and gas sector and fossil fuel subsidies [27], and has not been extended to cover RE and the development of its related fiscal policies.

For many years fossil fuel subsidies discouraged Indonesia's RE development, nonetheless the significant reduction of these subsidies in the past three years has not encouraged Indonesia's RE to take off. Since the President came into office in 2014, Joko Widodo has been successful in significantly reducing billions of dollars on fossil fuel subsidies spent for electricity and vehicle fuel since the early 2000s [28]. Figure 1 shows that the Indonesian government reduced the fossil fuel energy subsidy by 6.5 from IDR 341.8 trillion in 2014 to IDR 119.1 trillion in 2015.

The significant reduction of subsidies for electricity up to 20.4 trillion in 2016 is expected to shift fossil fuel energy use to $\mathrm{RE}$ and to stimulate actors who no longer receive subsidies to carry out energy-conservation activities except for some household segments i.e. those using below 450 volt-amperes (VA) and registered poor households using below $900 \mathrm{VA}$ who are still heavily subsidised [29]. 


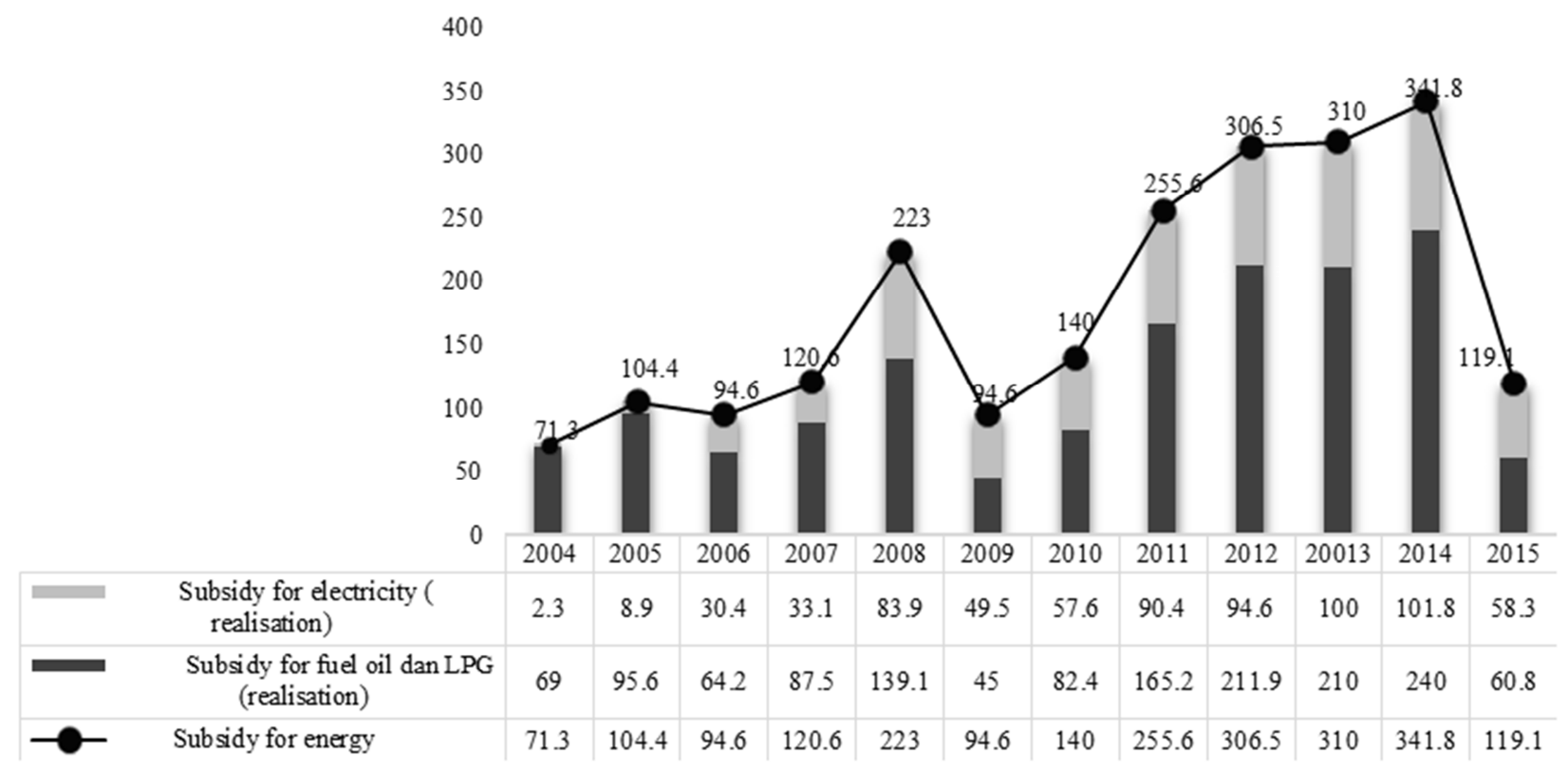

Source: Appendix 1, Presidential Regulation No. 22 Year 2017 on National Energy Plan.

Figure 1. Energy subsidies in Indonesia, 2004-2015 (IDR trillions).

The impact of subsidy removal on energy efficiency is as expected but this is not the case for the development of RE. The electricity subsidy for the majority of household segments is found to have positive effects, with energy savings of up to $7 \%$ [30]. Another study shows that changing the price of energy has had a similar energy-saving response on the part of firms, which have also tended to substitute their energy sources with other, possibly cheaper, alternatives [31].

Despite its significant reduction of fossil fuel subsidies, however, Indonesia's RE has been slowly taken off, and the high price of RE technology is arguably one of the reasons [32]. Domestic RE companies such as solar photovoltaic (PV) producers are consistently marginalised, with the majority of the components still imported [33]. Despite a $60 \%$ decrease in the price of solar PV over the last decade [34], the Indonesian government still opted for a quick shortcut deal by leasing 125 megawatt (MW) floating diesel power generators from Karadeniz Powership Zeyne, Turkey to fulfil short-term need in remote regions [35].

Multi-level weak governance and inconsistent regulations and policies form one of the largest barriers to economic development, both overall and for all types of RE development [36]. Long delays in geothermal power plant development are caused by unclear procedures for decentralisation to local authorities, which have few incentives to support geothermal energy development [4]. Local government offer little support for land acquisition [26]. A poor and siloed policy communication and weak coordination across government institutions exacerbate the situation [37]. In some regions at provincial and district levels, complex regulations about foreign investment and staffing persist [3], although the national government has put forward initiatives to simplify investment procedures in order to welcome investors, who can play a central role in significantly improving Indonesia's infrastructure.

Limited human and technical capacity and the poor integrity of low-ranking PT PLN officials slow RE development on the ground [38]. PT PLN has occupied a role as electricity generator, distributor and has been granted exclusive authority to transmit electricity across Indonesia. As one of Indonesian state-owned enterprises (SOEs), PT PLN has a long colonial history and is vertically integrated with a complex government bureaucratic system, as later discussed in section 5. PT PLN's poorly-educated local human resources at the local level may respond slowly to the technically-oriented nature of RE development [39] inhibiting knowledge transfer and on-the-ground technical adaptation.

The government has made some significant moves to overcome obstacles specific to particular energy sources. The National Energy Plan divides RE sources into seven categories [1]: geothermal energy, hydro, mini and micro hydro energy, bioenergy, solar PV energy, wind energy and tidal wave energy. The government has identified geothermal potential across Indonesia [40] and supports its development via the new Law No. 21 Year 2014, which replaces Law No. 27 Year 2003 on geothermal. The outstanding issue of land acquisition and permission for geothermal energy development is resolved by this new law, which no longer classifies it as mining operation [41]. Substantial financial support of approximately US\$275 million has been allocated to PT Sarana Multi Infrastruktur (PT SMI) through the Regulation of the Minister of Finance (PMK) No. 62/PMK.08/2017, to pay for the speculative geothermal exploration phase [42]. At the time of data collection the significant effort made to establish a project management unit to disburse this fund has been unsuccessful. 
Like geothermal energy development, hydro energy and bioenergy, which are expected to contribute significantly to the country's renewables, are growing slowly. Indonesia aims to harness hydro, mini hydro (below $2 \mathrm{MW}$ ) and micro hydro energy (below $500 \mathrm{~kW}$ ) after geothermal energy [43]. The potential for bio-energy other than from palm-oil and municipal-waste has not yet been fully identified. Many of these projects are delayed, severely affected by lack of financing and poor understanding on the part of financiers $[37,44]$.

There is a mismatch between investors' preferences and what can be promptly accommodated. Some solar PV and wind energy investors are interested in building large power plants where demand is high, but available land in such areas is limited. The main demand for energy is concentrated in Sumatra, Java and Bali, and with space in these areas limited, small and medium on- and off-grid solutions are more available to solar PV investors [45]. Indonesia is still in the early phase of exploiting tidal-wave energy, with development focusing on research and building technological capacity [46].

So far the government has promoted all RE sources with FiTs, but its constant change of tariffs sends a negative policy signal to investors. The changing tariffs are mainly driven by the changing leadership of the MEMR [47]. FiTs are supposedly a solution to RE development; however, the changing energy prices tends to present another barrier to the development of RE in Indonesia. The evolution of and changes in FiT policy in Indonesia are discussed in section 4. The next section explains the methodology used in this research.

\section{Methodology}

\subsection{Research Design}

This research is designed to improve understanding of the political economy of Indonesia's RE sector with regard to the development of fiscal policy for the sector. The aim is not to measure the impact of such fiscal policy but to describe the political interactions among key government institutions and their political interests, which inhibit the development of stable fiscal policy for the country's RE sector. By mapping the political interactions and the interests of the key stakeholders, this study offers a perspective on the various stakeholders' distance from the consensus, which may contribute to creating enabling policy environment in Indonesia and better conditions for investors wishing to support Indonesia's RE sector.

This research is developed based on the following hypothesis:

The more divergent the political interests of the key stakeholders in Indonesia's RE sector, the bigger the barriers to developing stable and effective fiscal policy that promotes the sector.

\subsection{Data}

This research uses primary and secondary qualitative data collected from key informant interviews, a literature review, and archive analysis.

The review of existing fiscal policies on RE uses secondary data from the fiscal policy database of the MOF in the period 2007-2017 and the MEMR policy database. The fiscal policies reviewed in this research were selected using a key-word search for 'energi terbarukan' (renewable energy) $[48,49]$ with main criteria set in Table 1. In addition, we considered some of the fiscal policies listed in 'A fiscal options paper on the energy sector' issued by the MOF (2016) [10], which provides a comprehensive list of fiscal policies in Indonesia until 2015 and complements the databases, which may omit older policies and others that only indirectly support RE development but remain relevant.

Table 1. Selection criteria for fiscal policy in Indonesia 's renewable energy sector.

\begin{tabular}{ll}
\hline Criteria & Description \\
\hline Energy-sector related & $\begin{array}{l}\text { Fiscal policy whose main text or appendix has a clause or clauses directly or indirectly related to energy sources, including } \\
\text { energy commodities and energy equipment such as electricity components or motors that use energy. This does not include } \\
\text { annual general budget allocation to the MEMR. }\end{array}$ \\
Energy-supply related & $\begin{array}{l}\text { Fiscal policy whose main text or appendix has a clause or clauses directly or indirectly aiming to improve the provision of } \\
\text { energy }\end{array}$ \\
Energy-demand related & $\begin{array}{l}\text { Fiscal policy whose main text or appendix has a clause or clauses directly or indirectly aiming to improve the amount of } \\
\text { energy used and access to energy across the country }\end{array}$ \\
Renewable-energy related & Fiscal policy whose main text or appendix has a clause or clauses directly aiming to improve the utilisation of RE sources \\
\hline
\end{tabular}

The primary data was primarily obtained from semistructured interviews with 37 respondents representing several institutional groups, namely the executive government, the legislative government, donors, civil society organisations, associations, research organisations, SOEs, and private companies (see Appendix 1; interview questionnaire available on request). The literature review covers relevant academic papers and the most recent media coverage of the topic (see section 2).

\subsection{Analytical Framework}

To understand the political economy of Indonesia's RE sector in related to fiscal policy development this research employs a problem-driven governance and political economy analysis [50]. This has three components. Figure 2 illustrates how these provide an analytical framework for the paper. The first component describes and identifies the problem that this paper addresses, with attention to the governance and political economy dimensions (see section 2). 


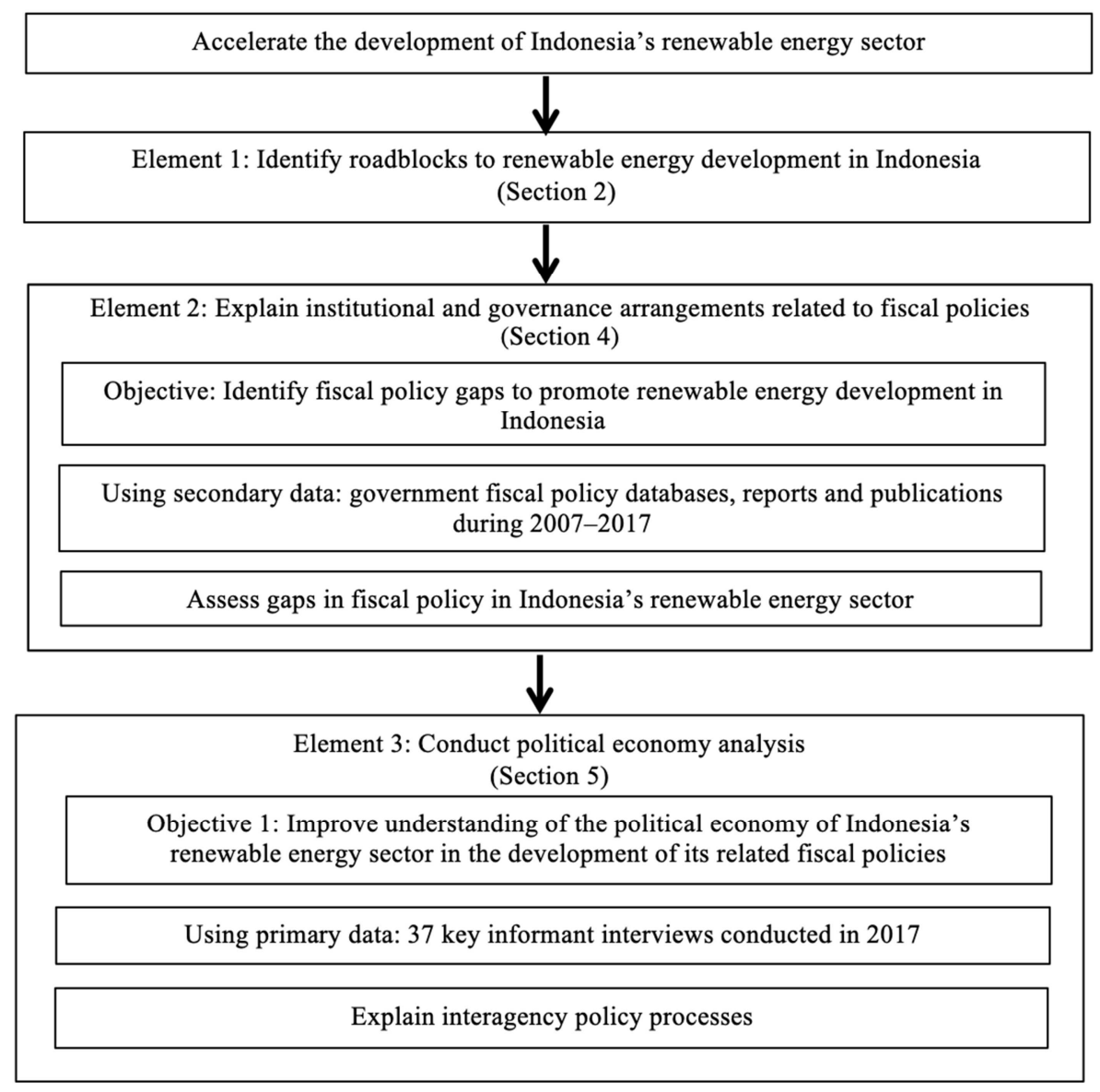

Figure 2. The analytical framework.

The second component is the institutional and governance arrangements that explain how these processes are supposed to work, and identification of which aspects are not operating effectively (see section 4). To identify the gaps in fiscal policy this paper uses a cluster approach and a metasynthesis method, a non-statistical technique for integrating, evaluating, and interpreting the findings from several qualitative studies [51] (see Figure 3).

Process Output

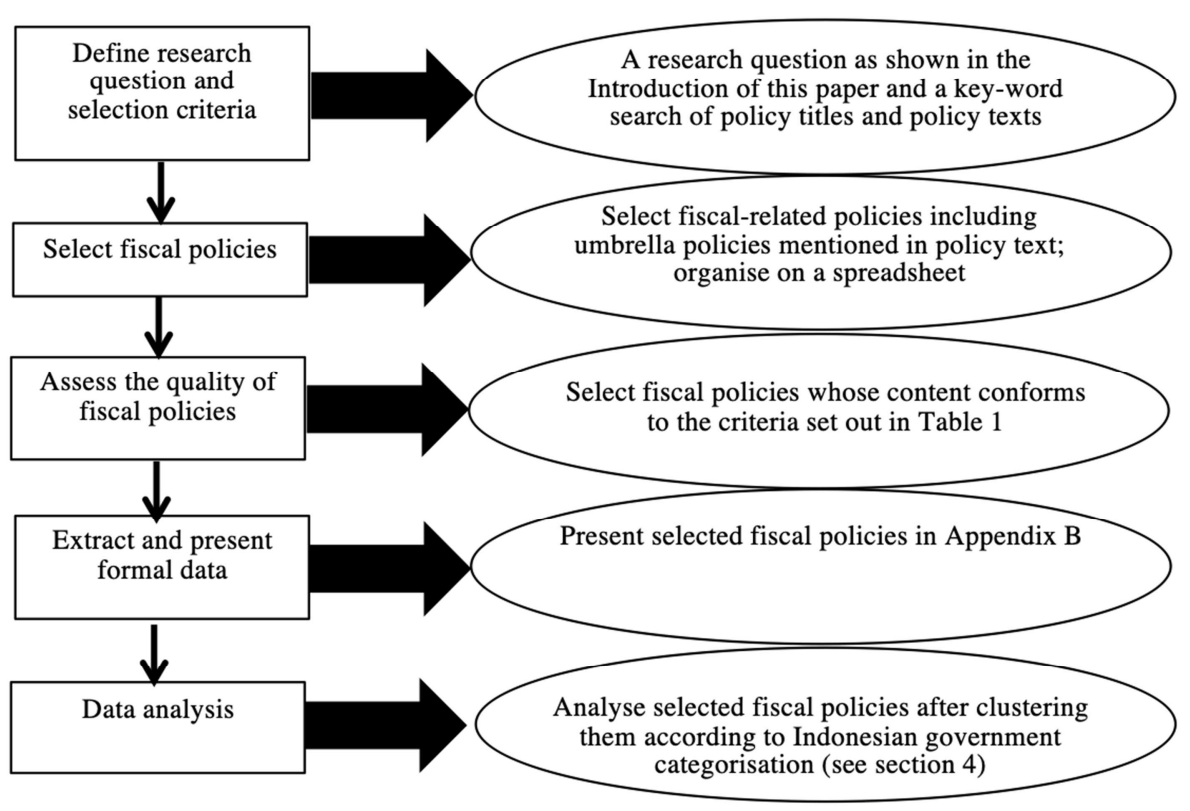

Figure 3. Meta synthesis process. 
The selected policies were clustered into the three categories used by the Indonesian government (see Appendix 2). First is government revenue and grant policy, which includes taxation and customs duty; second is government expenditure policy including subsidies and FiTs; and third is government financing policy, which includes financing, loans and guarantees.

The third component is concerned with the political economy and explains interagency policy processes using principal-agent theory (see section 5). It analyses the reasons behind governance failures related to fiscal policies, looking at the incentives and powers of various stakeholders and the informal practices by which decisions are made in practice. For instance, it explains the implications of excluding FiT from the authority of the MOF based on the formal mandate given to the MEMR with the implicit assumption of good coordination and communication between the two ministries.

The next section analyses the institutional and governance arrangements and explains the structure of Indonesia's fiscal policies and the Ministries which are responsible for.

\section{Fiscal Policy Gaps on Indonesia's Renewable Energy}

Indonesia has developed some fiscal policy options to support the development of its RE, and energy more broadly, to achieve its $35000 \mathrm{MW}$ target and larger development agenda, i.e. rural electrification, but to date, this target is far from reality [52]. This section discusses existing fiscal policy mainly consists of FiT policies developed and enacted by MEMR. Other fiscal policies such as tax breaks and income tax and VAT reduction have been developed only recently by the MOF. This section identifies what are the policy gaps developed by the MEMR and MOF.

\subsection{Feed-in-Tariff Policy Developments for Renewables}

In Indonesia the MEMR has a mandate to develop and enact various electrification policies, including FiTs, for RE development through Presidential Regulation Number 68 Year 2015. Since the early 2010s these policies have rapidly changed, influenced by a wide array of positive and negative circumstances. Its improved understanding of managing the complex and wide economic disparity across the Indonesian islands and the instability of foreign exchange is shown in the specificities of its FiT policies, including a classification based on various waste-to-energy technologies. Nonetheless, the lack of predictability in the changing MEMR leadership and of transparency and clarity regarding consultation on FiT policies prior to their enactment increases uncertainty and sends negative policy signals to investors. This section discusses and presents FiT policies before and since Ignasius Jonan come to office as the Minister of Energy and Mineral Resources.

\subsubsection{Indonesia's FiT Policies Before the JONAN Era}

Indonesia has a different FiT for each RE source.
Appendix C shows that those for waste-to-energy, bioenergy, geothermal energy, solar PV energy and hydropower have been revised at least once. Some changes in the case of waste-to-energy are driven by changing the currency used for FiT from Indonesian Rupiah to US dollar. A change in FiT for biogas, biomass and solar PV is also driven by geographical conditions: the more remote the regions and territories involved, the greater the incentive. The incentive factor is a strategic tool in the MEMR's promotion of energy development across the Indonesian islands. For example, the price of biomass per kilowatt of biomass paid by the PT PLN is multiplied by 1.7 when it is developed on Maluku and Papua Islands than when it is developed on Java Island.

The currency used and classification of areas across Indonesia are increasingly becoming uniform across RE sources. The MEMR uses the US dollar as its preferred currency payment for large and mega-scale RE development, while FiT policies for small and medium RE still use the Indonesian Rupiah. The US dollar is used to promote industrial actors' investment in RE development [53] increasing the necessity for PT PLN, and Indonesia as a country, to have a large US dollar reserve pot to pay for its FiT. The geographical incentive factor is also applied to energy sources whose FiTs were previously not differentiated based on area, such as biomass and solar PV. The area classification varies, and is more general in the case of geothermal energy and more specific in the case of solar PV.

This era is characterised by a more open and ambitious MEMR approach. Generally, while FiTs are high they are unsuccessfully deployed and implemented on the ground. The policy development process involves stakeholders through focus group discussions (FGD). For example, the development of MEMR regulation Number 19 Year 2016 took a year due to public consultation at a series of FGDs.

When the government has a limited budget for conducting FGDs and when its interagency coordination is not operating effectively, it can call for public input via social media platforms to minimise overlap; however this is not common practice in Indonesia's policy development system.

\subsubsection{Indonesia's FiT Policies After the Jonan Era}

Ignasius Jonan introduced new RE pricing for renewables in January 2017. The new FiTs are determined to use the cost of generation, or BPP (Biaya Pokok Penyediaan) Pembangkitan, per region as a reference point. The BPP is regulated under MEMR Regulation Number 24 Year 2017 and annually updated by the MEMR based on input submitted to it by PT PLN. The BPP for April 2017-March 2018 is stated in MEMR Ministerial Decision $1404 \mathrm{~K}$ /20/MEM/2017 (see Appendix D).

RE prices using the BPP system were introduced in MEMR Regulation Number 12 Year 2017. This regulation was enacted with very limited consultation with the MOF, resulting in a strong reaction from interested parties. The regulation was soon revised in an interim policy, MEMR Regulation Number 43 Year 2017, later confirmed by MEMR 
Regulation Number 50 Year 2017 in August 2017, with the BPP system in place. The issuance of policy in almost every quarter shows a limited window of opportunity for stakeholders to provide input and the uncertainty of energy policy in Indonesia. With the new BPP system the MEMR replaced the incentive factors in previous FiT policies and automatically gave significant authoritative power to PT PLN to differentiate tariffs across different areas of Indonesia according to the latter's own classification system.

MEMR Regulation Number 50 Year 2017, Indonesia's latest RE pricing policy, sets out direct selection and appointment methods with a build, own, operate, and transfer (BOOT) scheme for all types of RE as PT PLN's procurement method. This policy at last recognises energy sourced from the movement of and differences in seawater temperature. For hydro, biomass, biogas, and seawater energy it uses a direct selection method.1 For solar PV and wind power, the direct selection method is based on capacity quota. Municipal waste and geothermal energy will be procured by direct appointment based on MEMR Regulation Number 44 Year 2015 and MEMR Regulation Numbers 14 and 17 Year 2014. The latest RE pricing policy, Number 50, applies a universal policy to the BOOT scheme which requires the energy developer to return all project assets to the PT PLN after a certain period. This may not be suitable for biomass energy, whose land is usually owned by plantation companies which are less open to a land transfer. The BOOT scheme does not apply to municipal waste, and remains unregulated creating uncertainties and delaying potential investments. This latest FiT policy eliminates the open tender mechanism and makes Indonesia's RE industry less transparent.

Many independent power producers oppose the tariff framework under the BPP system, as the tariff for renewables is set at equal to or lower than the normal tariff for fossilfuel-generated electricity. Where local BPP is lower than national BPP, the applicable tariff will be set at a maximum of $85 \%$ of the local BPP for solar, wind, biomass and biogas energy, and $100 \%$ of the local BPP for municipal waste, geothermal, seawater and hydro energy. For example, before the Jonan era solar PV developments in DKI Jakarta were paid US\$ 14 cent/KwH under MEMR Regulation Number 19 Year 2016 (see Appendix C); after the Jonan era IPPs will only be paid $80 \%$ of the DKI Jakarta's BPP (see Appendix D): approximately US\$ 5.2 cents/KwH. In remote areas such as Nusa Tenggara Timur solar PV developments were paid 23 cents/KwH, and now will be paid only about US\$ 14.9 cents/KwH. The new BPP system generally offers lower tariffs for renewables and disincentivises IPPs from developing RE where electricity is already being generated efficiently.

Indonesia's RE pricing policies are becoming less consultative, allowing PT PLN to exercise its preferences to a great extent. The procedural constraints under which PT PLN

1 A procurement method where the energy suppliers were directly selected from a pool of preselected suppliers known as Daftar Penyedia Terseleksi (DPT) [70]. operates are significantly reduced by its authority to propose the BPP and select its supplier without an open tender process. PT PLN applies a two-stage selection process for RE projects implemented by third parties. First, PT PLN's suppliers select the RE company that they will use. Later the PT PLN either selects a supplier or puts the supply out to tender. This two-stage selection process can improve PT PLN's efficiency in finding readily-available RE suppliers. This preselection of energy suppliers, as described, has been developed: however there is limited information about the registration period for application for the first stage selection process. MEMR Regulation Number 50 Year 2017 gives PT PLN stronger administrative power to make deals with IPPs in the preselected pool behind closed doors. This policy may increase PT PLN's bureaucratic drift. This is further explained in section 5 .

Overall, the history of Indonesia's FiT development shows policy gaps in terms of high inconsistencies, a low attention to small and middle scale projects and very little attention to sustainability. RE prices before and after the Jonan era are significantly different, yet neither have introduced any differentiating factor for domestic and foreign power producers, although the idea of promoting nationallymanaged resources is strongly reflected in Indonesia's industrial policy [54]. The current RE pricing strategy implicitly focuses strongly on mega-scale infrastructure development, i.e. on-grid power plants, while expecting RE prices in areas where grids are available to be as low as those for the fossil fuel energy, and all managed as far as possible by the state. This strategy may incentivise IPPs to help Indonesia to achieve its electrification target in remote areas at the cost of marginalising domestic actors with significant potential for developing a sustainable pathway for Indonesia's RE sector.

\subsection{Other Fiscal Policies}

In addition to MEMR's FiTs the MOF has issued some fiscal policies that aim to support the development of Indonesia's RE in the form of government regulations, presidential regulations, presidential instructions, and Minister of Finance regulations (see Appendix B). Most of these regulations were developed as part of an overarching agenda to promote investment in priority industries, including RE.

The MOF classifies fiscal policy other than FiT into three categories: government revenues and grants, government financing, and government expenditure. Fiscal policy on government revenue and grants governs and manages the sources of government income such as import and custom duties and taxation. Government financing policy is related to government investment within and outside the country. The government's fiscal policy on expenditure relates to policies on the allocation of central government expenditure and transfers to local government. This section highlights the eligibility criteria and target audiences for several non-FiT fiscal policies issued to promote $\mathrm{RE}$ development in Indonesia in the three categories above. 


\subsubsection{Government Revenues and Grant Policies}

In 2010, the MOF issued an exclusive regulation for RE development through MOF Regulation Number 21/PMK.011/2010 concerning the provision of tax and customs facilities for activities related to the utilisation of RE. This regulation provides several incentives for RE development in the form of income tax, VAT, import duty and government-borne tax facilities. This regulation is linked to several general regulations concerning: (1) income tax facilities for investment in certain business fields and/or certain regions; (2) the import and/or delivery of certain strategic taxable goods exempted from value added tax; (3) import duty facilities for imports of machines, goods and materials for the construction or development of industries within the framework of investment; and (4) of constructing and developing power plants for public service.

The latest policy was released through Government Regulation Number 18 Year 2015 on Income Tax Facility for Investment on Specific Business Sectors and/or Specific Regions. The electrical equipment industry, waste management, and the procurement of electricity, gas, and geothermal energy can receive income tax reductions of up to $30 \%$ of the amount invested, allowed for six years at 5\% per year with accelerated amortisation. Article 3 of the Regulation states that eligible companies are those with a high investment value or a high volume of export, a high rate of labour absorption and high local content, although there is no direct definition of these criteria. The eligibility of companies is determined on a case-by-case basis by the MOF. This allows only large and mega investments in RE to receive sufficient attention from the Minister to result in fiscal incentives.

Another latest policy regarding income tax reduction shows that eligibility for tax reduction is restricted and should involve high-level officials. MOF Regulation Number 192/PMK.011/2014 states that since 2014, reductions in income tax should be proposed by the Minister of Industry and the Head of the Investment Coordinating Board. This amends MOF Regulation Number 130/PMK.011/2011, which requires only the authority of the MOF for decisions regarding income tax reduction for pioneering industries, including RE companies, as long as the investment is over IDR 1 trillion (US\$74.5 million). This size of investment is not relevant to many RE projects in Indonesia.

$\mathrm{RE}$ industries can benefit from import duty and VAT facilities including electric components for power-plant development as strategic goods. With the complexity of the application for import duty and VAT facilities, RE developers may only apply for these for a large quantity of imported components for industrial purposes. A small purchase of RE components such as solar PV panels for private use is not automatically exempted from VAT and import duty. RE developers are often restricted by MEMR Ministerial Decree Number 54 Year 2012, which obliges them to source as much as $38 \%$ of their RE equipment and components domestically; while this policy may be intended to promote local production, it limits the progress of RE development projects.

\subsubsection{Government Expenditure Policy on Promoting Renewable Energies}

Indonesia has some large expenditures on RE that are mainly channelled through SOEs. The Government of Indonesia has allocated IDR 3.3 trillion in the form of a loan to the state-owned electricity enterprise PT PLN to develop electricity infrastructure, and in addition has loaned the stateowned oil and gas enterprise, Pertamina, IDR 0.7 trillion to develop power plants that utilise new and RE sources and reduce the environmental impact of their development.

Another example of the government's expenditure policy is a budget allocated to rural energy development in the form of its Special Allocation Fund (DAK). MEMR Regulation Number 3 Year 2017 provides technical guidelines for the use of this fund in small-scale energy development, and is supported by the MEMR Regulation Number 39 Year 2017. The DAK for rural electrification prioritises the development of new and renewable resources such as micro hydropower plants with a capacity of less than $1 \mathrm{MW}$, off- and on-grid (connected to the PT PLN network) solar power plants, and biogas. Working units at the district level are responsible for the use of the fund and for directly organising the activities they finance.

\subsubsection{Government Financing Policies in Promoting Renewable Energies}

The MOF has developed financing policies to support the development of RE. In particular, the Geothermal Fund Facility (GFF) supports geothermal energy development. The GGF is designed to accelerate geothermal development, especially in the exploration phase. In May 2017 government investment of IDR 3 trillion, which had accumulated over five years, was allocated to PT SMI, but it has not yet been disbursed [55]. Previously the GFF had been hosted by the Government Investment Facility (PIP), the executing agency (MOF Regulation Number 03/PMK.011/2012 on GFF procedures, management and accountability). Due to institutional restructuring PIP was merged with PT SMI in 2015).

The GFF will be used to finance projects that have been coordinated with the MEMR and are listed in the Electricity Supply Business Plan (RUPTL), developed by PT PLN and approved by the MEMR to provide a projection of electrification targets, (mainly) on-grid electricity projects, and how these are to be financed. There are however design and implementation issues with these incentives: among others, although it was deposited, funding allocated to geothermal energy exploration was not disbursed until 2016, and financing for the development of RE does not yet cover the development of all types and scales of energy resources.

So far the fiscal policies issued by the MOF focus mainly on attracting large-scale investment such as in on-grid RE development, with geothermal energy receiving special treatment through a specific financing facility. The majority of MOF regulations tend to be ad hoc and employed to support the PT PLN in achieving Indonesia's energy targets through guarantees. Only government expenditure policies 
are used as a strategic tool to support small- and mediumscale projects, and government revenues, grants and financing policies have not yet been effectively designed to develop domestic RE industries throughout the RE supply chain, including micro-, small-, and medium-scale RE producers, suppliers and distributors.

\section{Political Economy of Indonesia's Renewable Energy}

Since the fall of Indonesia's New Order (1966-1998), its energy system has undergone a series of bureaucratic reforms that have been overshadowed by its past political hegemony, and remains uncoordinated. The government has continuously improved its energy services and issued laws responding to the growing demand for energy [56]. Law No. 30 Year 2009 on Electrification allows private-sector participation in Indonesia's RE development [57]. However, this is restricted by a Constitutional Court decision which allows private companies to participate in energy development with some conditions [58]. By a large majority, SOEs still dominate Indonesia's energy system: PT PLN remains the sole authority for electrification and transmission, while PT Pertamina is slowly entering the RE businesses but mainly covers the oil and gas sector. Despite the continuous development of energy policy, no single body in Indonesia is responsible for coordinating national energy goals and finding ways of achieving them.

The political history of SOEs is intertwined with the Indonesian government's complex bureaucratic system, whose coordination is still weak and siloed by government functions [59]. PT PLN was adopted to be a government agency from a Dutch Colonial Electrical Company, Nederlandche Indische Electriciteit Maatschappij (NIEM) in 1945 and later to become a SOE in 1965, and PT Pertamina, from the Royal Dutch Company in 1957 [11]. During the nationalisation of these colonial companies many leadership positions were entrusted to Indonesian ex-military officers [60]. For years SOEs were subject to much criticism about corruption, performance, accountability and lack of transparency; nonetheless the government maintains this system, arguing that is safeguards companies operating in areas of land with border and ownership conflicts among the government, communities, and companies [61].

A series of interviews identified the key stakeholders in Indonesia's RE sector. PT PLN holds immense administrative power in the sector. As the largest state-owned electricity enterprise in Indonesia, it has the sole mandate to manage electricity transmission. It also delivers some huge electricity development projects. However it must follow multiple principals with varying mandates from the MEMR, whose pricing policies can be executed only with the approval of the MOF. Mandates from other principals, i.e. the MSOE and the MOI, are linked to the PT PLN's functions but can clash in the absence of inter-ministerial coordination [62].

The evidence from a series of interviews reveals a multifaceted principal-agent problem in the institutional relationship between PT PLN and its key stakeholders. The problem appears to be strong due to two factors: first, conflicts between the principals and PT PLN as the executing agent, who plays a central role in managing the expectations of all principals, who have different vested interests [63]. Second, the cost of PT PLN strictly following one ministry jeopardises its political relationship with other ministries that support it when it needs political back-up [64].

Figure 4 illustrates the position of PT PLN and the various policy preferences of its principals. Before the enactment of MEMR Regulation Number 12 Year 2017, the MEMR mandated PT PLN to pay FiTs at above-market value. The interviews revealed a lack of consultation with PT PLN prior to giving the mandate. This aimed to attract investors to support the large-scale deployment of RE projects. In opposition to this, the MOF executes budget cuts and trims government expenditure, including on FiTs. In parallel to MOF, MSOE expects profits from PT PLN and hence encouraging lowering the tariffs that PT PLN take as a financial burden. Meanwhile the MOI, with a mandate to promote job creation and ensure industrial productivity, demands tariffs acceptable to major industrial actors and relies on MEMR to designs FiT policies that incentivise the growth of domestic RE industries. At the same time, the Ministry of Environment and Forestry (MOEF) expects RE to be developed quickly at a scale that will meet Indonesia's emission reduction targets [65].

With its principals' varying policy preferences, solid interministerial communication on policy development and implementation is needed. A discussion of policy options and the trade-offs involved would ideally include all of the principals and the agent, with the results of the discussion used as the basis of a collective decision on a position (see X in Figure 4) and a set of procedural constraints (see a ball in Figure 4) to limit the discretion of the PT PLN so that it functions to accommodate the objectives of all principals. The changing policy preferences that accompany a change in the leadership of the MEMR are often not communicated well across government functions, including those with minor role but a significant influence on off-grid RE, such as the MOEF, for the development of forest communities' access to energy, and the Ministry of Women's Empowerment and Children's Protection, for the promotion of gender inclusion in rural electrification [47, 62].

Due to this lack of coordination the MEMR does not consult properly with all the key stakeholders when setting energy prices. This creates disparities in knowledge and access to information associated with the principal-agency problem. Information is asymmetrically received by stakeholders or accessed exclusively by a small number of people. Often ministries are unaware of policies issued by other ministries, which leads to duplication and inconsistencies. For example, the Fiscal Policy Agency (BKF) was not properly consulted about the issuance of MEMR Regulation No. 12 Year 2017 on the Utilisation of RE Sources for Electricity Supply. Similarly, the MEMR was 
not fully aware of existing MOF regulations incentivising RE developers. There is evidence that only one MOF regulation on RE is included in the MEMR database at the time of the data was collected [49]. The interviews revealed that the coordination of the energy sector is carried out in an ad hoc way by the Coordinating Ministry of Economic Affairs and the Ministry of Marine Affairs. However, the latter was selected by the President Joko Widodo in 2014 due to a large number of offshore development projects [67]. Regardless of which ministry coordinates energy policy, there is a need for one ministry to take full control of coordinating the setting of energy prices in a structured and inclusive manner.

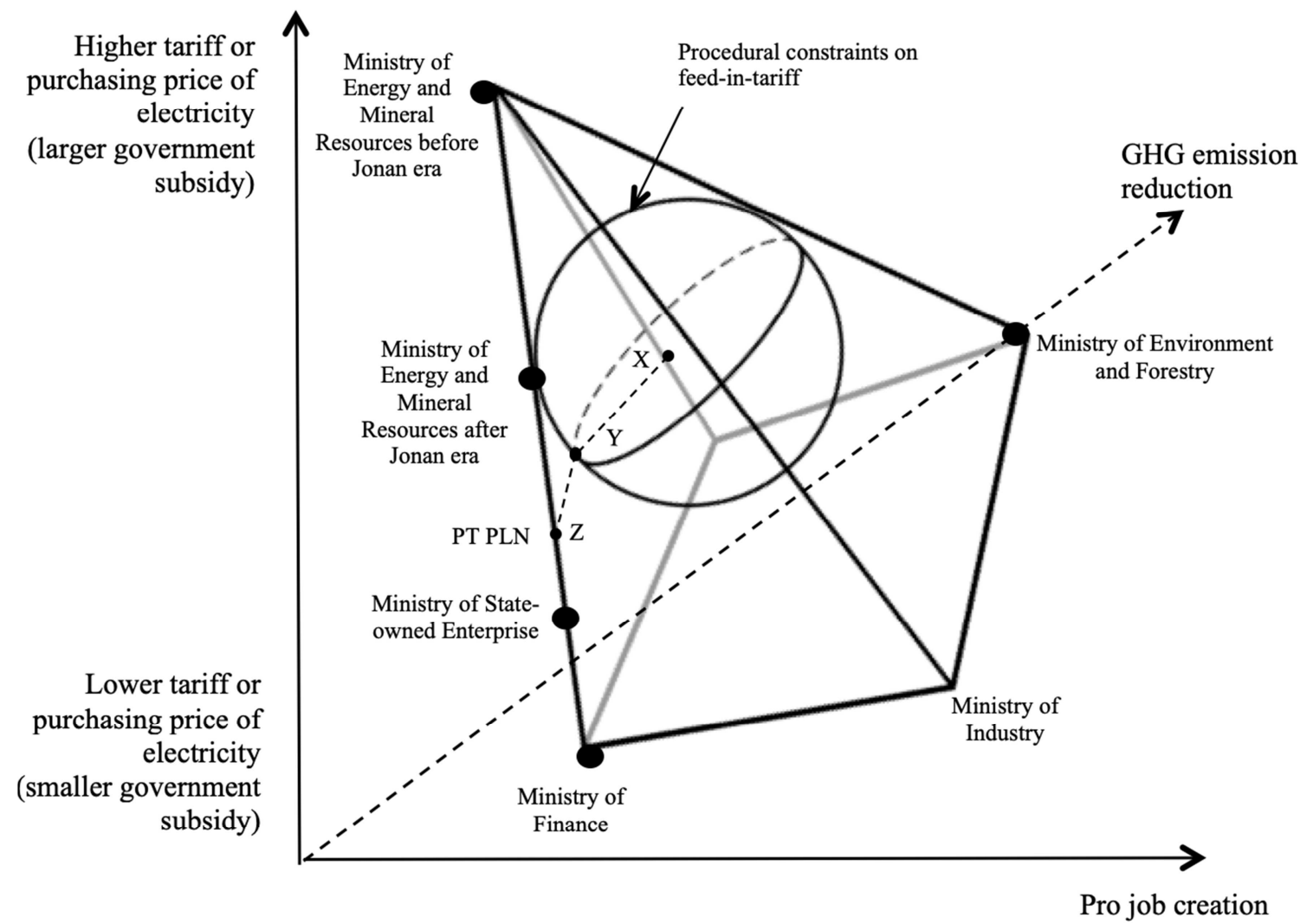

Source: Author's illustration adapted from Hix (2005, p. 30) [66]

Figure 4. Principal-agent relationships in Indonesia's renewable energy development.

Without a clear collective policy decision and a set of procedural constraints, there is room for PT PLN to misuse its considerable administrative power. According to classical public choice theory mid-level PT PLN officers had the option and the authority to arrange administration procedures and to allocate resources in their budget, including opening bids and signing purchasing power agreements (PPAs) that increase their personal income and benefits. When the principals' monitoring and evaluation system is weak, PT PLN is able to further exercise its administrative power and set its own policy preference at point $\mathrm{Z}$, bypassing the procedural constraint that the principals have set at point $\mathrm{Y}$ (so-called bureaucratic drift). Implementation falling outside the procedural constraints makes the PT PLN's policy suboptimal from all the stakeholders' points of view and can slow the implementation of RE in Indonesia due to political chaos. A sensitive expression of this was leaked when the MOF sent a letter to the MEMR complaining about PT PLN's financial and loan status endangering the government's balance of payments [68].

PT PLN also have the option to reveal or retain information that protects their pursuit of their own interests.
In the case of the personal aspirations of PT PLN officers are not in favour of the national RE industry they see the delivery of immediate low-cost electricity as more important than promoting national renewable industry [69], and have the power to arrange a daily expenditure amount that is closer to their ideal interests. Hence the implementation of RE development is far from the designated and collectivelyagreed objective.

With a robust system of monitoring and evaluation by independent parties and the National Parliament Commission VII, such drift can only be limited to the point acceptable to the principals at point Y, mainly because PT PLN's mid-level officers are also aware of the possible suspension of financial inflows due to misalignment between the MEMR's intended outcomes and the implementation. Therefore even if PT PLN has signed a contract with the IPPs and the IPPs deliver the projects, disparities between the purchasing price of electricity, or the misalignment of information between principals and between each principal and the PT PLN as the agent, can disrupt the implementation of RE projects in Indonesia. 


\section{Conclusions and Policy Recommendations}

Indonesia continually changing fiscal policies are influenced by diverging political interests of key RE stakeholders, and are overshadowed by multifaceted principal agent problems. This is worsened by a limited interinstitutional communication among RE stakeholders. While the country has set out a number of fiscal policies to attract high foreign and domestic investment in infrastructure projects, including for RE, political instability and policy uncertainty are the two major interconnected bottlenecks preventing Indonesia achieving its aspirations and ambitious RE targets. Reforms and improvements to interinstitutional communication and safeguards for the sustainability of Indonesian RE pricing policies are needed.

With a new RE pricing policy in the Jonan era, Indonesia's RE development will continue to heavily rely heavily on PT PLN to achieve its RE target. While PT PLN's authority to propose the ceiling tariffs or BPP in Indonesia gives it significant power and responsibility for setting the right prices to promote investment in RE, the MEMR has the opportunity to work with the MOI and MOF to create space and fiscal incentives for domestic RE actors on various scales and with differentiated BPP rates.

Overall, fiscal policies related to Indonesia's RE are developed rapidly but are pressurised by inconsistencies due to the MEMR's changing preferences and leadership, and to unclear and in transparent inter-ministerial communication among the key ministries. It suggests that the policy certainty and transparent policy development needs to be built based on a systematic coordination approach such as a periodical inter-ministerial energy forum where the government has the opportunity to collect input from its relevant stakeholders who have submitted their written input.

Based on these insights, this paper offers some policy recommendations, including the mitigation of unstable fiscal policy regulations using a stepwise approach to pricing policy for RE whose incentives decrease over time as its associated technology matures, for an assured minimum of two political terms. Indonesia can set widely accepted and aggregable targets that reflect the collective and consolidated commitment of stakeholders, including the PT PLN, just as the Paris Agreement achieved at the international level.

\section{Acknowledgements}

I would like to express my deepest appreciation to Koaksi Indonesia to facilitate discussions related to renewable energy sector in Indonesia.

\section{Note}

This research is fully independent and does not receive any funding support; declarations of interest: none.

\section{List of Abbreviation}

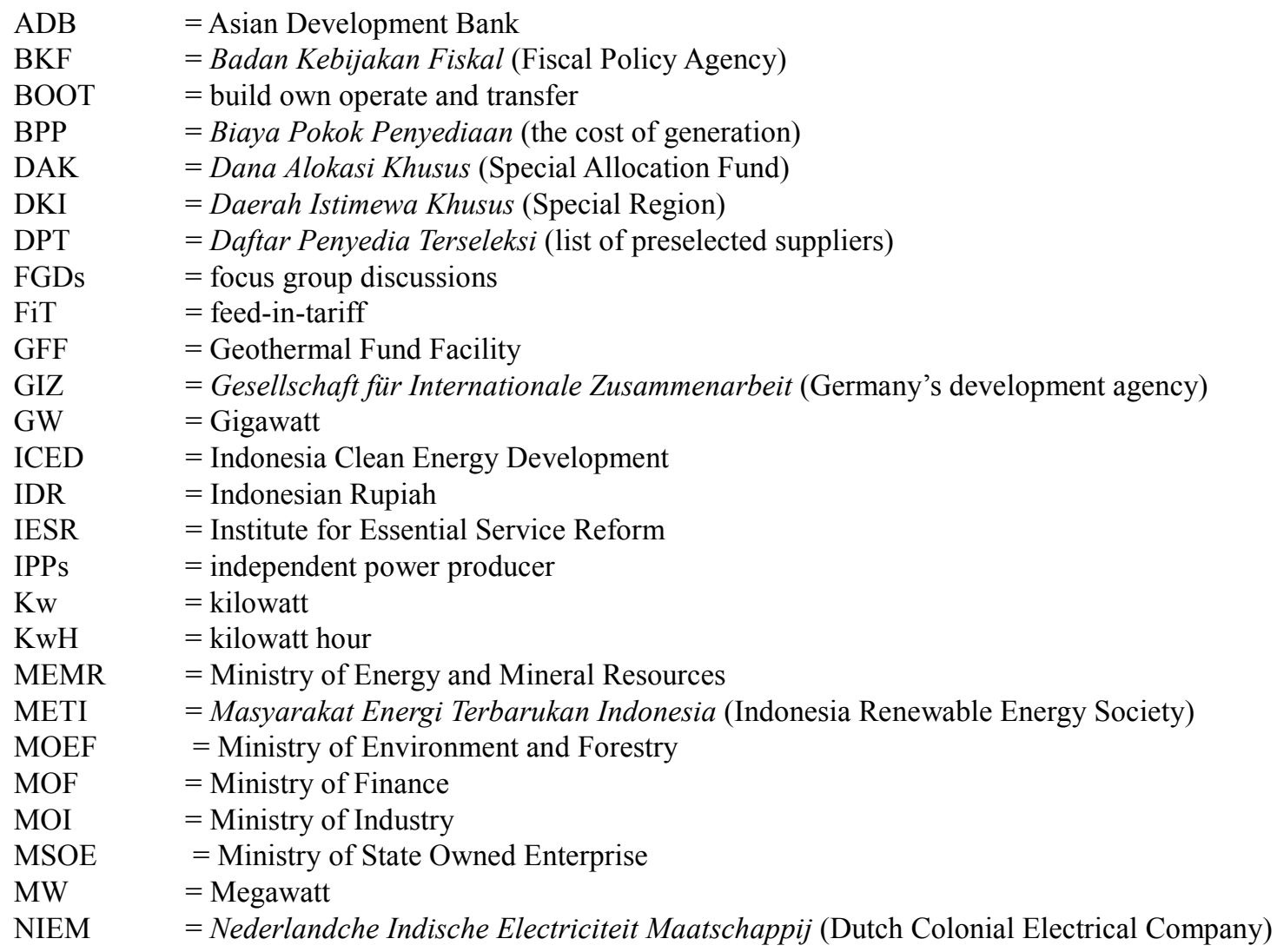




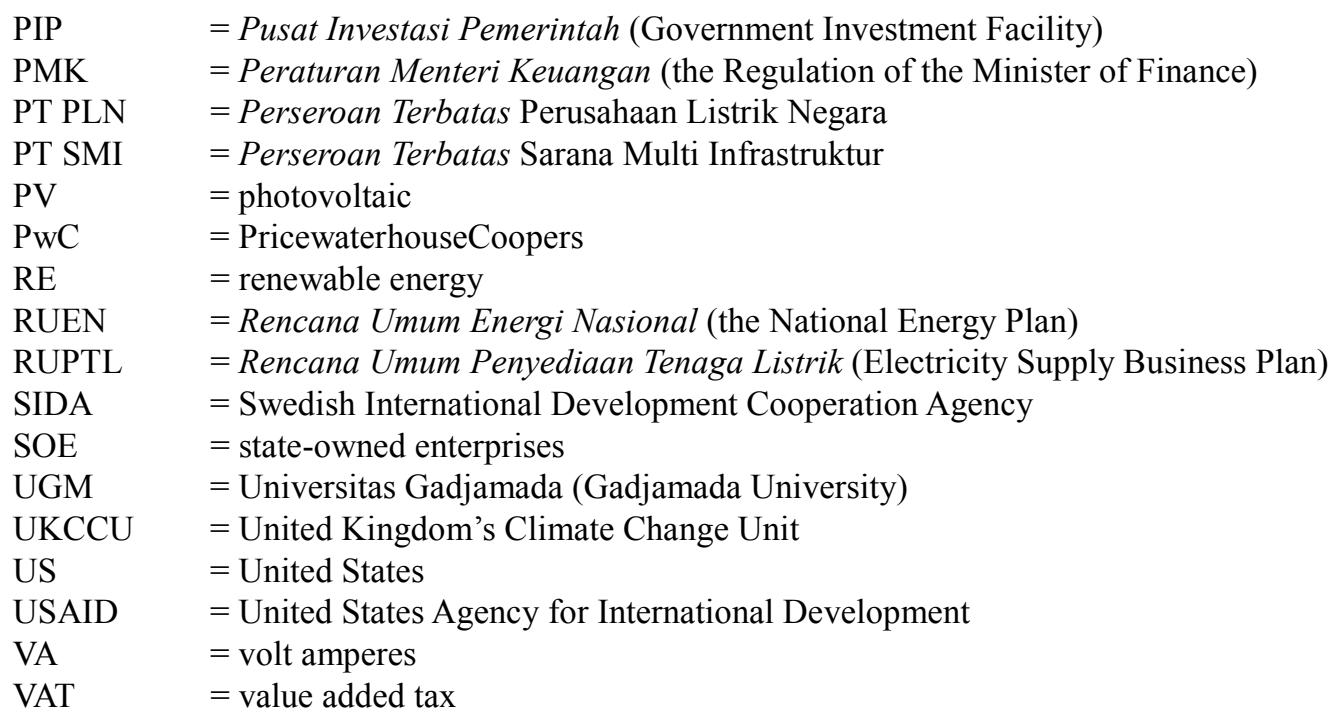

\title{
Appendix
}

\section{Appendix A. List of Respondents}

\author{
List of Respondents
}

\begin{tabular}{|c|c|c|}
\hline No & Category & Organisation \\
\hline 1 & Donor & GIZ \\
\hline 2 & Donor & SIDA \\
\hline 3 & Donor & World Bank \\
\hline 4 & Donor & UKCCU \\
\hline 5 & Donor & Denmark \\
\hline 6 & Donor & Canadian \\
\hline 7 & Donor & Netherlands \\
\hline 8 & Donor & USAID ICED \\
\hline 9 & Donor & $\mathrm{ADB}$ \\
\hline 10 & Executive Government & Directorate General of New Energy and Renewables, Ministry of Energy (MEMR) \\
\hline 11 & Executive Government & Fiscal Policy Agency, MOF \\
\hline 12 & Executive Government & Coordinating Ministry of Economic Affairs \\
\hline 13 & Executive Government & Former task force lead of renewable energy development in MEMR \\
\hline 14 & Executive Government & President's office \\
\hline 15 & Executive Government & NEC \\
\hline 16 & Executive Government & MEMR \\
\hline 17 & Executive Government & MEMR \\
\hline 18 & Legislative Government & National Parliament \\
\hline 19 & $\mathrm{CSO}$ & TEMPO \\
\hline 20 & $\mathrm{CSO}$ & Mongabay \\
\hline 21 & $\mathrm{CSO}$ & Indonesia Budget Centre \\
\hline 22 & $\mathrm{CSO}$ & UGM \\
\hline 23 & $\mathrm{CSO}$ & Kopernik \\
\hline 24 & Research organization & IESR \\
\hline 25 & Association & METI \\
\hline 26 & Association & Swedish Trade Council \\
\hline 27 & Media & Katadata \\
\hline 28 & Private company & PT Rimba Makmur Utama \\
\hline 29 & Private company & UPC Renewables \\
\hline 30 & Private company & Renewables Society \\
\hline 31 & Private company & $\mathrm{PwC}$ \\
\hline 32 & Private company & Eurocham Working Group on Energy \\
\hline 33 & Private company & Adaro \\
\hline 34 & Private company & METI \\
\hline 35 & Private sector & Business Sweden Jakarta \\
\hline 36 & SOE & Pertamina \\
\hline 37 & SOE & PT PLN \\
\hline
\end{tabular}




\section{Appendix B. Fiscal-related Policies Supporting Indonesia's Renewable Energy Development}

\section{Fiscal-related Policies Supporting Indonesia's Renewable Energy Development}

\begin{tabular}{|c|c|}
\hline Policy 2 & Explanation \\
\hline \multicolumn{2}{|l|}{ Indonesian Constitution Year 1945} \\
\hline \multicolumn{2}{|l|}{ Act } \\
\hline Act Number 17 Year 2006 Article 26 & Facilities on import duties: changes to Act Number 10 Year 1995 on Customs \\
\hline & $\begin{array}{l}\text { Investment. Article 18(4): net income reduction to a certain level in accordance with the } \\
\text { investment taken place within a certain period of time }\end{array}$ \\
\hline Act Number 25 Year 2007 & $\begin{array}{l}\text { Article } 18(5) \text { new venture investments which pioneering an industry may be given the incentive } \\
\text { of an income tax holiday }\end{array}$ \\
\hline Act Number 28 Year 2008 & Taxes and local levies including requirements to maintain the environment \\
\hline Act Number 36 Year 2008 & Fourth change to Act Number 7 Year 1983 about income tax \\
\hline Act Number 23 Year 2014 & About local government, e.g. for cooperation for RE development at local level \\
\hline \multicolumn{2}{|l|}{ Government Regulation } \\
\hline Government Regulation Number 31 Year 2007 & $\begin{array}{l}\text { VAT facilities: fourth change to Government Regulation Number } 12 \text { Year } 2001 \text { on exemption } \\
\text { from value added tax for the import and/or delivery of certain strategic taxable goods }\end{array}$ \\
\hline Government Regulation Number 62 Year 2008 & $\begin{array}{l}\text { Change to Government Regulation Number } 1 \text { Year } 2007 \text { on income tax facilities for capital } \\
\text { investment in certain business fields and certain regions }\end{array}$ \\
\hline Government Regulation Number 94 Year 2010 & $\begin{array}{l}\text { Income tax facilities: calculation of taxable income and the payment of income tax in the current } \\
\text { year }\end{array}$ \\
\hline Government Regulation Number 49 Year 2011 & $\begin{array}{l}\text { Change to Government Regulation Number } 1 \text { Year } 2008 \text { on government investment: PIP is direct } \\
\text { investment in infrastructure and other fields established by the Minister of Finance }\end{array}$ \\
\hline $\begin{array}{l}\text { Government Regulation Number } 52 \text { Year } 2011 \text { Article } \\
2\end{array}$ & $\begin{array}{l}\text { Income tax facilities: second change to Government Regulation Number } 1 \text { Year } 2007 \text { on income } \\
\text { tax facilities for capital investment in certain business fields and/or certain regions }\end{array}$ \\
\hline Government Regulation Number 22 Year 2014 & $\begin{array}{l}\text { Change to Government Regulation Number } 41 \text { Year 2013. Taxable luxury goods in the form of } \\
\text { motor vehicles subject to sales tax on luxury goods }\end{array}$ \\
\hline Government Regulation Number 79 Year 2014 & National Energy Policy (KEN) \\
\hline Government Regulation Number 9 Year 2016 & $\begin{array}{l}\text { Amendment to Government Regulation Number } 18 \text { Year } 2015 \text { regarding income tax facility for } \\
\text { investment in certain businesses and/or certain areas in certain regions }\end{array}$ \\
\hline \multicolumn{2}{|l|}{ Presidential Instruction and Presidential Regulation } \\
\hline Presidential Instruction Number 1 Year 2006 & Provision and utilisation of biofuel as an alternative fuel \\
\hline Presidential Regulation Number 4 Year $2010^{* * *}$ & Assigns PT PLN (Persero) to accelerate the development of power plants using RE, coal, and gas \\
\hline Presidential Regulation Number 48 Year 2011** & $\begin{array}{l}\text { Amendment to Presidential Regulation Number } 4 \text { Year } 2010 \text { regarding assignment to PT PLN } \\
\text { (Persero) to accelerate the development of power plant development using RE, coal and gas }\end{array}$ \\
\hline Presidential Regulation Number 61 Year 2011 & $\begin{array}{l}\text { National Action Plan on Greenhouse Gas Emission Reduction, known as RAN - GRK (Rencana } \\
\text { Aksi Nasional Penurunan Emisi Gas Rumah Kaca) }\end{array}$ \\
\hline Presidential Regulation Number 16 Year 2012 & $\begin{array}{l}\text { General plans for capital investment, e.g. the granting of facilities, ease of access, incentives for } \\
\text { capital investment, and promotion for capital investment at a local level }\end{array}$ \\
\hline Presidential Regulation Number 194 Year 2014*** & $\begin{array}{l}\text { Second Amendment to Presidential Regulation No. } 4 / 2010 \text { concerning the assignment of PT PLN } \\
\text { (Persero) to accelerate the development of power plants using RE, coal and gas }\end{array}$ \\
\hline \multicolumn{2}{|c|}{ Ministerial Decree (MD) and Minister of Finance (MOF) Regulation } \\
\hline MOF Regulation Number 117/PMK06/2006 & Biofuel: loan for \\
\hline MOF Regulation Number 79/PMK.05/2007 & Loan for Food Security and Energy (LFS-E)/Kredit Ketahanan Pangan dan Energi (KKP-E) \\
\hline MOF Regulation Number 154/PMK.011/2008 & $\begin{array}{l}\text { Exemption from import duties on capital goods in order to build and develop power plant industry } \\
\text { in the public interest }\end{array}$ \\
\hline MOF Regulation Number 218/PMK.05/2009 & $\begin{array}{l}\text { Change to PMK Number 99/PMK } 05 \text { year } 2008 \text { on guidelines for management of revolving fund } \\
\text { in government ministry/institution }\end{array}$ \\
\hline MD Number 296/KMK.09/2009 & Provision of business permit for PT SMI (Persero) as an infrastructure funding company \\
\hline MOF Regulation Number 21/PMK.011/2010* & Provision of tax and customs facilities for activities related to utilisation of RE \\
\hline MOF Regulation Number 24/PMK.011/2010 & Tax and customs facilities for activities related to utilisation of RE \\
\hline MOF Regulation Number 260/PMK.011/2010 & Guidelines for infrastructure guarantees in projects between government and business entities \\
\hline MOF Regulation Number 77/PMK.01/2011 & $\begin{array}{l}\text { Guidelines for the Implementation of PT PLN (Persero) for the Development of Power Plant and / } \\
\text { or Transmission by Using Renewable Energy, Coal and Gas Conducted Through Collaboration } \\
\text { With Independent Power Producer. }\end{array}$ \\
\hline MOF Regulation Number 130/PMK.011/2011 & Exemption or reduction facilities for agency's income tax \\
\hline MOF Regulation Number 139/PMK.011/2011* & $\begin{array}{l}\text { Guidelines for the establishment of business feasibility assurances for PT PLN (Persero) to build } \\
\text { power plants using RE, coal, and gas in cooperation with private power developers }\end{array}$ \\
\hline MOF Regulation Number 03/PMK.011/2012 & Guidelines and accountability for geothermal fund facility \\
\hline
\end{tabular}

2 Types and hierarchy of legislation is governed by Law Number 12 Year 2011, Articles 7 and 8, which state that the hierarchy consists of a) the Constitution of the Republic of Indonesia in 1945, b) the People's Consultative Assembly Decree; Law/Government Regulation in Lieu of Law; c) Government regulations; d) Presidential Decree; e) Provincial Regulation; and f) Regulation Regency/City. Types of legislation in addition to the above include regulations set by the People's Consultative Assembly, the House of Representatives, the Regional Representatives Council, the Supreme Court, the Constitutional Court, the Supreme Audit Board, the Judicial Commission, Bank Indonesia, the Minister, government agency and institution, established by Law or Government at the behest of the Act, the House of Representatives' Provincial Governor, House of Representatives District/City, regent/mayor, village head or equivalent. 


\begin{tabular}{l}
\hline Policy 2 \\
\hline MOF Regulation Number 144/PMK.011/2012 \\
MOF Regulation Number 225/PMK.011/2013* \\
MOF Regulation Number 173/PMK.011/2014* \\
MOF Regulation Number 159/PMK.010/2015 Regulation Number 188/PMK.10/2015 \\
MOF Regulation Number 66/PMK.010/2015
\end{tabular}

\section{Explanation}

Income tax facilities for capital investment on certain business entities and/or certain regions Procedures for Granting Feasibility Assurance by PT PLN (Persero) for the Development of Power Plant by Using Renewable Energy, Coal, and Gas Conducted through Cooperation with Private Power Developers.

Procedures for Granting Business Feasibility Assurance to PT PLN (Persero) for the Development of Power Plant by Using Renewable Energy, Coal and Gas Conducted Through Collaboration with Independent Power Producers.

Income tax reduction facility Change to MOF Regulation Number 176/PMK/011/2009 and to MOF Regulation Number 76/PMK.011/2012 on exemption from import duty for machinery, goods and materials used for constructing or developing industries in general for investment

Exemption of import duties on the import of capital goods for the development or industrial development of power plants for public use

Ministerial Decree (MD) and Minister of Energy and Mineral Resources (MEMR) Regulation

MEMR Regulation Number 2 Year 2004** Development of RE and energy conservation (development of green energy)

\section{MEMR Regulation Number 1 Year 2006}

MEMR Regulation Number 2 Year 2006**

MEMR Regulation Number 31 Year 2009

MEMR Regulation Number 32 Year 2009

MEMR Regulation Number 2 Year 2011

MEMR Regulation Number 1 Year 2012**

MEMR Regulation Number 4 Year 2012**

MEMR Regulation Number 10 Year 2012

MEMR Regulation Number 22 Year 2012

MEMR Regulation Number 17 Year 2013

MEMR Regulation Number 19 Year 2013

MEMR Regulation Number 21 Year 2013**

MEMR Regulation Number 25 Year 2013

MEMR Regulation Number 12 Year 2014

MEMR Regulation Number 17 Year 2014

MEMR Regulation Number 20 Year 2014

MEMR Regulation Number 22 Year 2014

MEMR Regulation Number 27 Year 2014

MEMR Regulation Number 19 Year 2015

MEMR Regulation Number 44 Year 2015

MEMR MD Number 3051/K/30/MEM/2015**

MEMR Regulation Number 19 Year 2016

MEMR Regulation Number 21 Year 2016

MEMR Regulation Number 12 Year 2017**

MEMR Regulation Number 39 Year 2017**

MEMR Regulation Number 43 Year 2017**

MEMR Regulation Number 50 Year 2017**
Procedures for purchasing power and/or leasing etwork in order to provide electric power in the public interest

Development of medium-scale power plant

Pricing policy for PT PLN (Persero) to purchase power from small and medium RE power plants if there is electricity power excess (replaced by MEMR Regulation Number 4 Year 2012) Ceiling tariff on geothermal energy purchased by PT PLN (Persero) (replaced by MEMR Regulation Number 2 Year 2011)

Assignment to PT PLN (Persero) to purchase geothermal energy and ceiling tariff for geothermal energy purchased by PT PLN (Persero) (replaced by MEMR Regulation Number 22 Year 2012) Amendment to MEMR Regulation Number 15 Year 2010 regarding the list of electricity power development projects using RE, coal, and gas and related transmission

FiT small-scale energy: Pricing policy for PT PLN (Persero) to purchase power from small and medium RE-based power plan or electricity power excess (replacing MEMR Regulation Number 31 Year 2009)

Implementation of new energy and RE (related to physical activities)

FiT of geothermal/delegation of power purchase and geothermal energy power plants to and price benchmarking by PT PLN (Persero) from geothermal energy power plant (replaced by MEMR

Regulation Number 17 Year 2014)

FiT PV solar/power purchase by PT PLN (Persero) from photovoltaic solar power plant (replaced by MEMR Regulation Number 19 Year 2016)

FiT waste to energy/power purchase by PT PLN (Persero) from city waste-based power plant (replaced by MEMR Regulation Number 44 Year 2015)

Second Amendment to Regulation of MEMR Number 15 Year 2010 regarding list of requirements for the development of electric power using RE, coal and gas and related transmission Change to MEMR Regulation Number 32 Year 2008 on the provision, utilization, and business administration of biofuel as alternative fuel

Power purchase from hydro energy power plant by PT PLN (Persero)

Power purchase of geothermal energy by PT PLN (Persero) (replacing MEMR Regulation Number 22 Year 2012)

Second change to MEMR Regulation Number 32 Year 2008 on the provision, utilisation, and business administration of biofuel as alternative fuel

Change to MEMR Regulation Number 12 Year 2014 on power purchase from hydro energy power plants by PT PLN (Persero)

Power Purchase from biomass energy power plant by PT PLN (Persero) replaced by MEMR

Regulation Number 21 Year 2016

Purchase of Hydro Energy with the a capacity of up to 10 megawatt by PT PLN (Persero)

(replacing MEMR Regulation Number 12 Year 2014)

Power Purchase of waste-to-energy by PT PLN (Persero) (replacing MEMR Regulation Number

19 Year 2013)

The establishment of Sumba Island as an iconic of renewable-energy island

Power purchase of Solar PV by PT PLN (Persero), replacing MEMR Regulation Number 17 Year 2013

Power purchase of biomass and biogas energy by PT PLN (Persero) (replacing MEMR

Regulation Number 27 Year 2014)

Utilisation of RE for electricity supply (replaced by MEMR Regulation Number 50 Year 2017) Implementation of physical activity for new energy utilisation and RE and energy conservation Amendment to Regulation of the MEMR Number 12 Year 2017 on the use of RE source for electricity supply (replaced by MEMR Regulation Number 50 Year 2017) Utilisation of RE for electricity supply

Sources: *MOF's database (2017), found with a keyword search for 'renewable energy'; ** MEMR database (2017d) using a keyword search for 'renewable energy', *** presented in both MOF (2017) and MEMR databases (2017d): the rest is taken from MOF (2016) FiT policies. 


\section{Appendix C. Feed-in Tariff for Indonesia's Renewable Energy}

\section{Feed-in-Tariff for Indonesia's Renewable Energy}

\begin{tabular}{|c|c|c|c|c|c|c|}
\hline Source of Energy & \multicolumn{5}{|l|}{ Tariff (per kWh) } & $\begin{array}{l}\text { Policy number } \\
\text { and note }\end{array}$ \\
\hline $\begin{array}{l}\text { All types of small } \\
\text { and medium RE } \\
* *\end{array}$ & \multicolumn{5}{|c|}{$\begin{array}{l}\text { IDR } 656 / \mathrm{kWh} \times \mathrm{F} \text {, if connected to medium electrical voltage } \\
\text { IDR } 1,004 / \mathrm{kWh} \times \mathrm{F} \text {, if connected to low electrical voltage } \\
\text { (see note below table for value of } \mathrm{F} \text { ) }\end{array}$} & $\begin{array}{l}\text { MEMR Regulation } \\
\text { Number } 4 \text { Year } \\
2012\end{array}$ \\
\hline $\begin{array}{l}\text { City waste with } \\
\text { zero waste } \\
\text { technology } \\
\text { (thermochemical) } \\
* *\end{array}$ & \multicolumn{5}{|c|}{$\begin{array}{l}\text { Capacity up to } 20 \text { megawatts, medium and high electrical voltage USD } 18.77 \text { cents } / \mathrm{kWh} \text {, low USD } 22.43 \\
\text { cents/kWh } \\
\text { Capacity above } 20 \text { megawatts and below } 50 \text { megawatt, USD } 15.95 \mathrm{cents} / \mathrm{kWh} \\
\text { Capacity above } 50 \text { megawatts, USD } 13.14 \text { cents } / \mathrm{kWh} \\
\text { Previous policies: } \\
\text { if connected to medium electrical voltage, previously IDR } 1,450 / \mathrm{kWh}, \text { IDR } 1,050 / \mathrm{kWh} \\
\text { if connected to low electrical voltage, previously IDR } 1,798 / \mathrm{kWh} \text {, IDR } 1,398 / \mathrm{kWh} \\
\text { Capacity up to } 20 \text { megawatt medium and high electrical voltage USD } 16.55 \mathrm{cents} / \mathrm{kWh} \text {, low USD } 20.16 \\
\text { cents/kWh } \\
\text { Previous policies: } \\
\text { if connected to medium electrical voltage (previously IDR } 1,250 / \mathrm{kWh}, \text { IDR } 850 / \mathrm{kWh} \text { ) } \\
\text { if connected to low electrical voltage (previously IDR } 1,598 / \mathrm{kWh}, \text { IDR } 1,198 / \mathrm{kWh})\end{array}$} & $\begin{array}{l}\text { MEMR Regulation } \\
\text { number } 44 \text { Year } \\
\text { 2015; previously } \\
\text { MEMR Regulation } \\
\text { Number } 19 \text { Year } \\
\text { 2013, MEMR } \\
\text { Regulation } \\
\text { Number } 4 \text { Year } \\
2012\end{array}$ \\
\hline \multicolumn{7}{|c|}{ Feed-in-Tariff for Indonesia's Biomass ** } \\
\hline \multirow{3}{*}{\multicolumn{2}{|c|}{ Location/Area }} & Purchasing $\mathbf{p}$ & cent per kWh & & & \multirow{3}{*}{$\mathbf{F}$} \\
\hline & & $<20$ MW & & $20 \mathrm{MW}-50 \mathrm{MW}$ & $>50 \mathrm{MW}$ & \\
\hline & & Low voltage & Medium to high voltage & High voltage & High voltage & \\
\hline \multicolumn{2}{|l|}{ Java Island } & $16.00 \times \mathrm{F}$ & $13.5 \times \mathrm{F}$ & $11.48 \times \mathrm{F}$ & $10.18 \times \mathrm{F}$ & 1.00 \\
\hline \multicolumn{2}{|l|}{ Sumatra Island } & $16.00 \times \mathrm{F}$ & $13.5 \times \mathrm{F}$ & $11.48 \times \mathrm{F}$ & $10.18 \times \mathrm{F}$ & 1.15 \\
\hline \multicolumn{2}{|l|}{ Sulawesi Island } & $16.00 \times \mathrm{F}$ & $13.5 \times \mathrm{F}$ & $11.48 \times \mathrm{F}$ & $10.18 \times \mathrm{F}$ & 1.25 \\
\hline \multicolumn{2}{|c|}{ Kalimantan Island } & $16.00 \times \mathrm{F}$ & $13.5 \times \mathrm{F}$ & $11.48 \times \mathrm{F}$ & $10.18 \times \mathrm{F}$ & 1.30 \\
\hline \multirow{2}{*}{\multicolumn{2}{|c|}{ Bali, Bangka Belitung, Lombok Island }} & $16.00 \times \mathrm{F}$ & $13.5 \times \mathrm{F}$ & $11.48 \times \mathrm{F}$ & $10.18 \times \mathrm{F}$ & 1.50 \\
\hline & & $16.00 \times \mathrm{F}$ & $13.5 \times \mathrm{F}$ & $11.48 \times \mathrm{F}$ & $10.18 \times \mathrm{F}$ & 1.60 \\
\hline \multicolumn{2}{|c|}{ Riau, Nusa Tenggara, and other islands } & $16.00 \times \mathrm{F}$ & $13.5 \times \mathrm{F}$ & $11.48 \times \mathrm{F}$ & $10.18 \times \mathrm{F}$ & 1.70 \\
\hline
\end{tabular}

Note: The table is based on MEMR Regulation Number 21 Year 2016; previously MEMR Regulation Number 27 Year 2014, MEMR Regulation Number 4 Year 2012; previous policies: if connected to medium electrical voltage (previously IDR 1,150/kWh x F; IDR 975/kWh x F); if connected to low electrical voltage (previously IDR 1,500/kWh x F; IDR 1,325/kWh x F) (see note for the unit of F).

\section{Feed-in-Tariff for Indonesia's Biogas**}

\begin{tabular}{|c|c|c|c|c|c|}
\hline \multirow{3}{*}{ Location/Area } & \multicolumn{4}{|c|}{ Purchasing price USD cent per $\mathrm{kWh}$} & \multirow{3}{*}{$\mathbf{F}$} \\
\hline & \multicolumn{2}{|l|}{$<20 \mathrm{MW}$} & \multirow{2}{*}{$\begin{array}{l}20 \mathrm{MW}-50 \mathrm{MW} \\
\text { High voltage }\end{array}$} & \multirow{2}{*}{\begin{tabular}{|l|}
$>50 \mathrm{MW}$ \\
High voltage
\end{tabular}} & \\
\hline & Low voltage & Medium to high voltage & & & \\
\hline Java Island & $13.14 \times \mathrm{F}$ & $10.64 \times \mathrm{F}$ & $9.05 \times \mathrm{F}$ & $8.51 \times \mathrm{F}$ & 1.00 \\
\hline Sumatra Island & $13.14 \times \mathrm{F}$ & $10.64 \times \mathrm{F}$ & $9.05 \times \mathrm{F}$ & $8.51 \times \mathrm{F}$ & 1.15 \\
\hline Sulawesi Island & $13.14 \times \mathrm{F}$ & $10.64 \times \mathrm{F}$ & $9.05 \times \mathrm{F}$ & $8.51 \times \mathrm{F}$ & 1.25 \\
\hline Kalimantan Island & $13.14 \times \mathrm{F}$ & $10.64 \times \mathrm{F}$ & $9.05 \times \mathrm{F}$ & $8.51 \times \mathrm{F}$ & 1.30 \\
\hline Bali, Bangka Belitung, Lombok Island & $13.14 \times \mathrm{F}$ & $10.64 \times \mathrm{F}$ & $9.05 \times \mathrm{F}$ & $8.51 \times \mathrm{F}$ & 1.50 \\
\hline Riau, Nusa Tenggara, and other islands & $13.14 \times \mathrm{F}$ & $10.64 \times \mathrm{F}$ & $9.05 \times \mathrm{F}$ & $8.51 \times \mathrm{F}$ & 1.60 \\
\hline Maluku and Papua & $13.14 \times \mathrm{F}$ & $10.64 \times \mathrm{F}$ & $9.05 \times \mathrm{F}$ & $8.51 \times \mathrm{F}$ & 1.70 \\
\hline
\end{tabular}

Note: The table is based on MEMR Regulation Number 21 Year 2016; previously MEMR Regulation Number 27 Year 2014, MEMR Regulation Number 4 Year 2012; Previous policies: if connected to medium electrical voltage; (previously IDR 1,050/kWh x F; IDR 975/kWh x F), if connected to low electrical voltage (previously IDR $1,400 / \mathrm{kWh} \times \mathrm{F}$; IDR $1,325 / \mathrm{kWh} \times \mathrm{F}$ ) (see note below table for the value of F)

\section{Feed-in-Tariff for Indonesia's Geothermal}

\begin{tabular}{llll}
\hline \multirow{2}{*}{ Commercial Operation Date (COD) } & \multicolumn{4}{l}{ Price Ceiling (cent USD/kWh) } \\
\cline { 2 - 4 } & Area I & Area II & Area III \\
\hline 2015 & 11.8 & 17.0 & 25.4 \\
2016 & 12.2 & 17.6 & 25.8 \\
2017 & 12.6 & 18.2 & 26.2 \\
2018 & 13.0 & 18.8 & 26.6 \\
2019 & 13.4 & 19.4 & 27.0 \\
2020 & 13.8 & 20.0 & 27.4 \\
2021 & 14.2 & 20.6 & 27.8 \\
\hline
\end{tabular}




\begin{tabular}{llll}
\hline \multirow{2}{*}{ Commercial Operation Date (COD) } & \multicolumn{2}{l}{ Price Ceiling (cent USD/kWh) } \\
\cline { 2 - 4 } & Area I & Area II \\
\hline 2022 & 14.6 & 21.3 & 21.9 \\
2023 & 15.0 & 22.6 & 28.3 \\
2024 & 15.5 & 23.3 & 29.2 \\
2025 & 15.9 & 29.6 & 2.3 \\
\hline
\end{tabular}

Note: The table is based on MEMR Regulation Number 17 Year 2014, replacing MEMR Regulation Number 22 Year 2012; Area I: Sumatra, Java, and Bali; Area II: Sulawesi, NTB, NTT, Halmahera, Maluku, Irian Jaya, and Kalimantan; Area III: Isolated areas in Areas I \& II, most of whose electricity is derived from fossil-fuel-based power plants

\section{Feed-in-Tariff for Indonesia's Solar PV}

\begin{tabular}{lll}
\hline Location & Capacity quota (MWp) & Purchasing price (USD cent/kWh) \\
\hline DKI Jakarta & & \\
West Java & 150.0 & 14.5 \\
Banten & & \\
Central Java and DIY Jogjakarta & & 16.0 \\
East Java & 5.0 & 15.0 \\
Bali & 5.0 & 15.0 \\
Lampung & 10.0 & 17.0 \\
South Sumatra, Jambi and Bengkulu & 5.0 & 16.0 \\
Aceh & 25.0 & 15.5 \\
North Sumatra & 5.0 & 17.0 \\
West Sumatra & 4.0 & 17.0 \\
Riau and Riau Islands & 5.0 & 17.0 \\
Bangka Belitung & 5.0 & 16.0 \\
West Kalimantan & 4.0 & 16.5 \\
South and Central Kalimantan & 3.0 & 17.0 \\
East and North Kalimantan & 5.0 & 16.0 \\
North and Central Sulawesi and Gorontalo & 5.0 & 18.0 \\
South, South East and West Sulawesi & 5.0 & 23.0 \\
West Nusa Tenggara & 3.5 & 23.0 \\
East Nusa Tenggara & 3.0 & 25.0 \\
Maluku and North Maluku & 2.5 & \\
Papua and West Papua & & \\
\hline
\end{tabular}

Papua and West Papua

Note: The table is based on MEMR Regulation Number 19 Year 2016 (previously MEMR Regulation Number 17 Year 2013; previous policy: Permitted price ceiling: USD 25 cents $/ \mathrm{kWh}$, USD 30 cents $/ \mathrm{kWh}$, if a solar power plant uses PV model with at least $40 \%$ produced domestically

Feed-in-Tariff for Indonesia's Mini and small hydro

\begin{tabular}{|c|c|c|c|c|}
\hline \multirow{2}{*}{ Electrical Voltage } & \multirow{2}{*}{ Location/Area } & \multicolumn{2}{|c|}{ Purchasing Price from Hydro power plant (USD cent kWh) } & \multirow{2}{*}{$\mathbf{F}$} \\
\hline & & Yr. 1-8 & Yr. 9-20 & \\
\hline \multirow{6}{*}{ Medium voltage (up to. $10 \mathrm{MW}$ ) } & Java, Bali and Madura & $12.00 \times \mathrm{F}$ & $7.50 \times \mathrm{F}$ & 1.00 \\
\hline & Sumatra & $12.00 \times \mathrm{F}$ & $7.50 \times \mathrm{F}$ & 1.10 \\
\hline & Kalimantan and Sulawesi & $12.00 \times \mathrm{F}$ & $7.50 \times \mathrm{F}$ & 1.20 \\
\hline & NTB dan NTT & $12.00 \times \mathrm{F}$ & $7.50 \times \mathrm{F}$ & 1.25 \\
\hline & Maluku, Maluku Utara & $12.00 \times \mathrm{F}$ & $7.50 \times \mathrm{F}$ & 1.30 \\
\hline & Papua and Papua Barat & $12.00 \times \mathrm{F}$ & $7.50 \times \mathrm{F}$ & 1.60 \\
\hline \multirow{6}{*}{ Low voltage (up to $250 \mathrm{~kW}$ ) } & Java, Bali and Madura & $12.00 \times \mathrm{F}$ & $9.00 \times \mathrm{F}$ & 1.00 \\
\hline & Sumatra & $12.00 \times \mathrm{F}$ & $9.00 \times \mathrm{F}$ & 1.10 \\
\hline & Kalimantan and Sulawesi & $12.00 \times \mathrm{F}$ & $9.00 \times \mathrm{F}$ & 1.20 \\
\hline & NTB and NTT & $12.00 \times \mathrm{F}$ & $9.00 \times \mathrm{F}$ & 1.25 \\
\hline & Maluku, Maluku Utara & $12.00 \times \mathrm{F}$ & $9.00 \times \mathrm{F}$ & 1.30 \\
\hline & Papua and Papua Barat & $12.00 \times \mathrm{F}$ & $9.00 \times \mathrm{F}$ & 1.60 \\
\hline
\end{tabular}

Note: The table is based on MEMR Regulation Number 19 Year 2015 replacing MEMR Regulation Number 22 Year 2014, changing MEMR Regulation Number 12 Year 2014

Previous Feed-in-Tariff for Indonesia's Mini and small hydro

\begin{tabular}{|c|c|c|c|c|c|c|}
\hline \multirow{2}{*}{$\begin{array}{l}\text { Electrical } \\
\text { Voltage }\end{array}$} & \multirow[t]{2}{*}{ Location/Area } & \multicolumn{2}{|c|}{$\begin{array}{l}\text { Multi-function purchasing } \\
\text { price*(IDR/kWh) }\end{array}$} & \multicolumn{2}{|c|}{$\begin{array}{l}\text { Purchasing Price from Hydro power } \\
\text { plant (IDR/kWh) }\end{array}$} & \multirow[t]{2}{*}{$\mathbf{F}$} \\
\hline & & Yr. 1 - 8 & Yr. 9-20 & Yr. 1-8 & Yr. 9-20 & \\
\hline \multirow{4}{*}{$\begin{array}{l}\text { Medium Voltage } \\
\text { (up to. } 10 \mathrm{MW} \text { ) }\end{array}$} & Java, Bali and Madura & $967.5 \times \mathrm{F}$ & $675 \times \mathrm{F}$ & $1,075 \times \mathrm{F}$ & $750 \times \mathrm{F}$ & 1 \\
\hline & Sumatra & $967.5 \times \mathrm{F}$ & $675 \times \mathrm{F}$ & $1,075 \times \mathrm{F}$ & $750 \times \mathrm{F}$ & 1.1 \\
\hline & Kalimantan and Sulawesi & $967.5 \times \mathrm{F}$ & $675 \times \mathrm{F}$ & $1,075 \times \mathrm{F}$ & $750 \times \mathrm{F}$ & 1.2 \\
\hline & NTB dan NTT & $967.5 \times \mathrm{F}$ & $675 x \mathrm{~F}$ & $1,075 \times \mathrm{F}$ & $750 \times \mathrm{F}$ & 1.25 \\
\hline
\end{tabular}




\begin{tabular}{|c|c|c|c|c|c|c|}
\hline \multirow{2}{*}{$\begin{array}{l}\text { Electrical } \\
\text { Voltage }\end{array}$} & \multirow[t]{2}{*}{ Location/Area } & \multicolumn{2}{|c|}{$\begin{array}{l}\text { Multi-function purchasing } \\
\text { price*(IDR/kWh) }\end{array}$} & \multicolumn{2}{|c|}{$\begin{array}{l}\text { Purchasing Price from Hydro power } \\
\text { plant (IDR/kWh) }\end{array}$} & \multirow[t]{2}{*}{$\mathbf{F}$} \\
\hline & & Yr. 1 - 8 & Yr. 9-20 & Yr. 1-8 & Yr. 9-20 & \\
\hline \multirow{8}{*}{$\begin{array}{l}\text { Low Voltage (up } \\
\text { to } 250 \mathrm{~kW} \text { ) }\end{array}$} & Maluku, Maluku Utara & $967.5 \times \mathrm{F}$ & $675 \times \mathrm{F}$ & $1,075 \times \mathrm{F}$ & $750 \times \mathrm{F}$ & 1.3 \\
\hline & Papua and Papua Barat & $967.5 \times \mathrm{F}$ & $675 \times \mathrm{F}$ & $1,075 \times \mathrm{F}$ & $750 \times \mathrm{F}$ & 1.6 \\
\hline & Java, Bali and Madura & $1,143 \times \mathrm{F}$ & $693 \times \mathrm{F}$ & $1,075 \times \mathrm{F}$ & $770 \times \mathrm{F}$ & 1 \\
\hline & Sumatra & $1,143 \times \mathrm{F}$ & $693 \times \mathrm{F}$ & $1,075 \times \mathrm{F}$ & $770 \times \mathrm{F}$ & 1.1 \\
\hline & Kalimantan and Sulawesi & $1,143 \times \mathrm{F}$ & $693 \times \mathrm{F}$ & $1,075 \times \mathrm{F}$ & $770 \times \mathrm{F}$ & 1.2 \\
\hline & NTB and NTT & $1,143 \times \mathrm{F}$ & $693 \times \mathrm{F}$ & $1,075 \times \mathrm{F}$ & $770 \times \mathrm{F}$ & 1.25 \\
\hline & Maluku, Maluku Utara & $1,143 \times \mathrm{F}$ & $693 \times \mathrm{F}$ & $1,075 \times \mathrm{F}$ & $770 \times \mathrm{F}$ & 1.3 \\
\hline & Papua and Papua Barat & $1,143 \times \mathrm{F}$ & $693 \times \mathrm{F}$ & $1,075 \times \mathrm{F}$ & $770 \times \mathrm{F}$ & 1.6 \\
\hline
\end{tabular}

Note: The table is based on MEMR Regulation Number 22 Year 2014

Appendix note: *utilises reservoir/dam and/or irrigation channel. ${ }^{*}$ for electrical capacity of up to $10 \mathrm{MW}$ or for excess power. $\mathrm{F}$ (incentive factor based on geographical location of purchasing) for small- and medium-scale RE: $F=1$ for Java and Bali, F = 1.2 for Sumatra and Sulawesi: $F=1.3$ for Kalimantan, NTB, and NTT; F $=1.5$ for Maluku and Papua. F value applied to energy from city waste with zero waste technology, city waste with sanitary landfill technology, biomass and biogas: $\mathrm{F}=1$ for Java; $\mathrm{F}=1.15$ for Sumatra; $\mathrm{F}=1.25$ for Sulawesi; $\mathrm{F}=1.3$ for Kalimantan; $\mathrm{F}=1.5$ for Bali, Bangka Belitung, Lombok; F = 1.6 for Riau archipelago, Papua, and others.

\section{Appendix D. BPP's PT PLN for April 2017-March 2018}

BPP’s PT PLN for April 2017 - March 2018

\begin{tabular}{|c|c|c|c|}
\hline Area & $\begin{array}{l}\mathrm{BPP} / \mathrm{kWh} \\
(\mathrm{Rp})\end{array}$ & $\begin{array}{l}\text { BPP/kWh (US\$ cent } / \mathrm{kWh}) * \text { for fossil } \\
\text { fuel and municipal waste, geothermal, } \\
\text { sea water and hydro energy }\end{array}$ & $\begin{array}{l}\text { BPP/kWh (US\$ cent } / \mathbf{k W h}) \\
\text { for solar, wind, biomass } \\
\text { and biogas energy }\end{array}$ \\
\hline Sumatra & 1,194 & 8.98 & 7.63 \\
\hline \multicolumn{4}{|l|}{ A. Northern Part of Sumatra } \\
\hline A.1. Aceh & 1,383 & 10.39 & 8.83 \\
\hline A.1.a. Weh Island & 1,733 & 13.02 & 11.07 \\
\hline A.1.b. Simeuleu Island & 1,817 & 13,65 & 11.60 \\
\hline A.2. North Sumatra & 1,235 & 9.28 & 7.89 \\
\hline A.2.a. Nias & 2,049 & 15.40 & 13.09 \\
\hline \multicolumn{4}{|l|}{ B. Central and South Sumatra } \\
\hline B.1. West Sumatra & 1,074 & 8.07 & 6.86 \\
\hline B.1.a. Mentawai Islands & 2,096 & 15.75 & 13.39 \\
\hline B.2. Riau and its outer islands & 1,349 & 10.14 & 8.62 \\
\hline B.2.a. Bintan & 1,583 & 11.9 & 10.12 \\
\hline B.2.b. Tanjung Balai Karimun & 1,706 & 12.82 & 10.90 \\
\hline B.2.c. Natuna & 2,089 & 15.70 & 13.34 \\
\hline B.2.d. Anambas & 2,149 & 16.15 & 13.73 \\
\hline B.3. South Sumatra, Jambi, Bengkulu (S2JB) & 1,046 & 7.86 & 6.68 \\
\hline B.3.a Enggano Island & 2,322 & 17.45 & 14.83 \\
\hline B.4. Lampung & 1.034 & 7.77 & 6.60 \\
\hline C. Bangka & 1.817 & 13.66 & 11.61 \\
\hline D. Belitung & 1.619 & 12.17 & 10.34 \\
\hline \multirow[t]{2}{*}{ E. Sub-system for other small islands } & 2,096 & 15.75 & 13.39 \\
\hline & & & 0 \\
\hline Jawa Bali & 868 & 6.52 & 5.54 \\
\hline A. DKI Jakarta & 867 & 6.51 & 5.53 \\
\hline A.1. Thousand Islands (unconnected to Jawa Bali Grid) & 2,332 & 17.52 & 14.89 \\
\hline B. Banten & 866 & 6.51 & 5.53 \\
\hline B.1. Panjang Island & 2,332 & 17.52 & 14.89 \\
\hline C. West Java & 866 & 6.51 & 5.53 \\
\hline D. Central Java & 868 & 6.52 & 5.54 \\
\hline D.1. Karimun Java & 2,332 & 17.52 & 14.89 \\
\hline E. East Java & 870 & 6.54 & 5.56 \\
\hline E.1. Madura (isolated) & 2,332 & 17.52 & 14.89 \\
\hline E.2. Bawean & 1,964 & 14,76 & 12.55 \\
\hline E.3. Gili Ketapang & 2,332 & 17.52 & 14.89 \\
\hline F. Bali & 881 & 6.62 & 5.63 \\
\hline $\begin{array}{l}\text { Three Nusa system (Nusa Penida, Nusa Lembongan, Nusa } \\
\text { Ceningan) }\end{array}$ & 1,745 & 13.11 & 11.14 \\
\hline G. Other small sub-systems & 2,332 & 17.52 & 14.89 \\
\hline Kalimantan & 1,373 & 10.31 & 8.76 \\
\hline A. West Kalimantan & 1,655 & 12.43 & 10.56 \\
\hline B. South and Central Kalimantan & 1,203 & 9.04 & 7.68 \\
\hline
\end{tabular}




\begin{tabular}{|c|c|c|c|}
\hline Area & $\begin{array}{l}\text { BPP/kWh } \\
\text { (Rp) }\end{array}$ & $\begin{array}{l}\text { BPP/kWh (US\$ cent } / \mathbf{k W h}) * \text { for fossil } \\
\text { fuel and municipal waste, geothermal, } \\
\text { sea water and hydro energy }\end{array}$ & $\begin{array}{l}\text { BPP/kWh (US\$ cent } / \mathbf{k W h}) \\
\text { for solar, wind, biomass } \\
\text { and biogas energy }\end{array}$ \\
\hline C. East and North Kalimantan & 1,357 & 10.20 & 8.67 \\
\hline D. Other small sub-systems & 2,332 & 17.52 & 14.89 \\
\hline Sulawesi and Nusa Tenggara & 1,421 & 10.68 & 9.08 \\
\hline A. North and Central Sulawesi and Gorontalo & 1,696 & 12.75 & 10.84 \\
\hline A.1. Manado, Gorontalo, Kotamobagu & 1,669 & 12.54 & 10.66 \\
\hline A.2. Toli-Toli & 2,026 & 15.22 & 12.94 \\
\hline A.3. Tahuna & 2,332 & 17.52 & 14.89 \\
\hline A.4. Palu (grid South Sulawesi) & 1,016 & 7.63 & 6.48 \\
\hline A.5. Luwuk & 1,759 & 13.22 & 11.24 \\
\hline B. South, South East and West Sulawesi & 1,078 & 8.10 & 6.88 \\
\hline B.1. South Sulawesi & 1,016 & 7.63 & 6.48 \\
\hline B.2. Kendari & 1,801 & 13.53 & 11.50 \\
\hline B.3. Bau-Bau & 2,137 & 16.06 & 13.65 \\
\hline B.4. Selayar & 2,114 & 15.88 & 13.50 \\
\hline C. South West Nusa & 1,821 & 13.68 & 11.63 \\
\hline C.1. Bima & 1,880 & 14.12 & 12.00 \\
\hline C.2. Lombok & 1,629 & 12.24 & 10.40 \\
\hline C.3. Sumbawa & 1,978 & 14.87 & 12.64 \\
\hline D. South East Nusa & 2,332 & 17.52 & 14.89 \\
\hline D.1. Sumba & 1,887 & 14.18 & 12.05 \\
\hline D.2. Timor & 2,226 & 16.73 & 14.22 \\
\hline D.3. West Flores & 1,751 & 13.16 & 11.19 \\
\hline D.4. East Flores & 2,070 & 15.55 & 13.22 \\
\hline E. Other small sub-systems & 2,332 & 17.52 & 14.89 \\
\hline Maluku and Papua & 2,008 & 15.09 & 12.83 \\
\hline A. Maluku and North Maluku & 2,305 & 17.32 & 14.72 \\
\hline A.1. Ambon & 1,680 & 12.62 & 10.73 \\
\hline A.2. Seram & 2,330 & 17,51 & 14.88 \\
\hline A.3. Saparua & 1,626 & 12.22 & 10.387 \\
\hline A.4. Buru & 1,728 & 12.98 & 11.033 \\
\hline A.5. Ternate - Tidore & 1,971 & 14.81 & 12.59 \\
\hline A.6. Sanana & 1,811 & 13.61 & 11.57 \\
\hline A.7. Bacan & 1,811 & 13.61 & 11.57 \\
\hline A.8. Halmahera (Tobelo, Malifut, Jailolo, Sofifi, Maba) & 1,685 & 12.67 & 10.77 \\
\hline A.9. Daruba & 1,587 & 11.93 & 10.14 \\
\hline A.10. Tual & 1,657 & 12.45 & 10.58 \\
\hline A.11. Dobo & 2,063 & 15.50 & 13.17 \\
\hline A.12. Saumlaki & 1,686 & 12.67 & 10.77 \\
\hline B. Papua and West Papua & 1,802 & 13.54 & 11.51 \\
\hline B.1. Jayapura & 1,959 & 14.72 & 12.51 \\
\hline B.2. Sarmi & 2,332 & 17.52 & 14.89 \\
\hline B.3. Biak & 1,753 & 13.17 & 11.19 \\
\hline B.4. Serui & 1,778 & 13.36 & 11.35 \\
\hline B.5. Nabire & 1,604 & 12.06 & 10.25 \\
\hline B.6. Wamena & 2,332 & 17.52 & 14.89 \\
\hline B.7. Timika & 1,786 & 13.42 & 11.41 \\
\hline B.8. Merauke & 1,704 & 12.80 & 10.88 \\
\hline B.9. Tanah Merah & 1,704 & 12.80 & 10.88 \\
\hline B.10. Manokwari & 1,760 & 13.23 & 11.24 \\
\hline B.11. Sorong & 1,305 & 9.81 & 8.34 \\
\hline B.12. Teminabuan & 2,332 & 17.52 & 14.89 \\
\hline B.13. Fak Fak & 2,332 & 17.52 & 14.89 \\
\hline B.14. Kaimana & 2,332 & 17.52 & 14.89 \\
\hline B.15. Bintuni & 2,332 & 17.52 & 14.89 \\
\hline B.16. Raja Ampat & 2,332 & 17.52 & 14.89 \\
\hline C. Other small sub-systems & 2,332 & 17.52 & 14.89 \\
\hline National BPP & 983 & 7.39 & 6.28 \\
\hline
\end{tabular}

Source: MEMR Decision No. 1404 K/20/MEM/2017 concerning generation cost of PT PLN (Persero) Year 2016 valid in the period April 2017-March 2018. * US\$ $1=$ Rp. 13,307

Note: maximum of $85 \%$ of the local BPP for solar, wind, biomass and biogas energy and $100 \%$ of local BPP for municipal waste, geothermal, sea water and hydro energy. 


\section{References}

[1] MEMR. Appendix I for the Presidential Regulation Number 22 Year 2017 on Indonesia's National Energy Plan. Jakarta, Indonesia, Indonesia: The Government of Indonesia; 2017.

[2] Arumingtyas L. Banyak Kepentingan Politik Bermain, Energi Terbarukan pun Lambat, Malah Dorong Batubara. Mongabay 2016. http://www.mongabay.co.id/2016/09/06/banyakkepentingan-politik-bermain-energi-terbarukan-punlambat-malah-dorong-batubara/ (accessed November 7, 2017).

[3] Dutu R. Challenges and policies in Indonesia's energy sector. Energy Policy 2016;98:513-9. doi:https://doi.org/10.1016/j.enpol.2016.09.009.

[4] Winters MS, Cawvey M. Governance Obstacles to Geothermal Energy Development in Indonesia. J Curr Southeast Asian Aff Vol 34, No 1 2015:27-56.

[5] Roy J, Ghosh D, Ghosh A, Dasgupta S. Fiscal instruments: crucial role in financing low carbon transition in energy systems. Curr Opin Environ Sustain 2013;5:261-9. doi:http://dx.doi.org/10.1016/j.cosust.2013.05.003.

[6] ESDM. ESDM: Buku Panduan 2017. http://ebtke.esdm.go.id/category/18/buku.panduan (accessed December 26, 2017).

[7] Panggabean G. Kementerian ESDM dan GIZ Luncurkan Buku Panduan Pembiayaan Bioenergi. Industri.bisnis.com 2017. http://industri.bisnis.com/read/20171213/44/718145/kementeri an-esdm-dan-giz-luncurkan-buku-panduan-pembiayaanbioenergi (accessed January 24, 2018).

[8] BKPM. Kontak Center PTSP Pusat 2017. http://www.bkpm.go.id/id/kontak/pusat-layanan-terpadu\# (accessed December 26, 2017).

[9] Nurmayanti. Pengusaha Kecewa DPR Tolak Subsidi Energi Baru Terbarukan. Liputan6 2016.

[10] MOF. Fiscal policy options for the energy sector in support of Indonesia's Sustainable Development. Jakarta, Indonesia: 2016.

[11] Halimanjaya A. Climate mitigation finance in leveraging private investments in Indonesia. J Sustain Financ Invest 2017:1-25. doi:10.1080/20430795.2017.1318461.

[12] The World Bank. International Bank for Reconstruction and Development Program Document on a Proposed Loan in the Amount of US \$500 Million to the Republic of Indonesia 20152015.

[13] MCAI. Green Prosperity Facility. MCAI 2017.

[14] Chang Y, Fang Z, Li Y. Renewable energy policies in promoting financing and investment among the East Asia Summit countries: Quantitative assessment and policy implications. Energy Policy 2016;95:427-36. doi:https://doi.org/10.1016/j.enpol.2016.02.017.

[15] Bakhtyar B, Sopian K, Zaharim a., Salleh E, Lim CH. Potentials and challenges in implementing feed-in tariff policy in Indonesia and the Philippines. Energy Policy 2013;60:41823. doi:10.1016/j.enpol.2013.05.034.

[16] Fathoni AM, Utama NA, Kristianto MA. A Technical and Economic Potential of Solar Energy Application with Feed-in Tariff Policy in Indonesia. Procedia Environ Sci 2014;20:8996. doi:https://doi.org/10.1016/j.proenv.2014.03.013.

[17] Nasruddin, Alhamid MI, Daud Y, Surachman A, Sugiyono A, Aditya HB, et al. Potential of geothermal energy for electricity generation in Indonesia: A review. Renew Sustain Energy Rev 2016;53:733-40. doi:https://doi.org/10.1016/j.rser.2015.09.032.

[18] Parry I. Designing Fiscal Policy to Address the External Costs of Energy. 2014.

[19] Carraro C, Pandey S, Stone S. Why Fiscal Policy Matters for a Green Economy Transition. Rev Environ Energy Econ 2015;January 29.

[20] Gunningham N. Managing the energy trilemma: The case of Indonesia. Energy Policy 2013;54:184-93. doi:http://dx.doi.org/10.1016/j.enpol.2012.11.018.

[21] Hasan MH, Mahlia TMI, Nur H. A review on energy scenario and sustainable energy in Indonesia. Renew Sustain Energy Rev 2012;16:2316-28. doi:http://dx.doi.org/10.1016/j.rser.2011.12.007.

[22] Mujiyanto S, Tiess G. Secure energy supply in 2025: Indonesia's need for an energy policy strategy. Energy Policy 2013;61:31-41.

doi:http://dx.doi.org/10.1016/j.enpol.2013.05.119.

[23] Jakarta Globe. Indonesia's Coal Kings. Jakarta Globe 2011.

[24] Attwood C. Financial Supports for Coal and Renewables in Indonesia. Geneva, Switzerland: 2017.

[25] Dartanto T. Reducing fuel subsidies and the implication on fiscal balance and poverty in Indonesia: A simulation analysis. Energy Policy 2013;58:117-34. doi:http://dx.doi.org/10.1016/j.enpol.2013.02.040.

[26] Marquardt J. A Struggle of Multi-level Governance: Promoting Renewable Energy in Indonesia. Energy Procedia 2014;58:87-94. doi:https://doi.org/10.1016/j.egypro.2014.10.413.

[27] Zain MA. Politics of Law on the State Control of Oil and Gas in Indonesia: Gas Liberalization and the Hesitancy of Constitutional Court. J Indones Leg Stud Vol 1 No 01 Establ Indones Leg Concept 2017.

[28] Ihsanuddin. 3 Tahun Jokowi-JK, Pemerintah Terus Pangkas Subsidi BBM dan Listrik. Kompas.com 2017.

[29] Listrik.org. Tarif Dasar Listrik PLN Desember 20172017. http://listrik.org/pln/tarif-dasar-listrik-pln/ (accessed December 22, 2017).

[30] Burke PJ, Kurniawati S. Electricity subsidy reform in indonesia: demand-side effects on electricity use. Meet. Energy Demands Emerg. Econ., Singapore: International Association for Energy Economics; 2015.

[31] Rentschler J, Kornejew M. Energy price variation and competitiveness: Firm level evidence from Indonesia. Energy Econ 2017;67:242-54. doi:https://doi.org/10.1016/j.eneco.2017.08.015.

[32] Tempo. Proyek Energi Bersih Jokowi Terancam Gagal 2017. 
[33] KumparanBISNIS. Produksi Panel Surya PLTS di Dalam Negeri Terus Menurun 2017.

[34] DetikFinance. Harga Panel Surya Makin Murah, Turun 60\% dalam 6 Tahun 2017.

[35] Munthe BC. Indonesia turns to floating power stations to meet short-term needs. Reuters 2015.

[36] Collier P, Dollar D. Aid allocation and poverty reduction. Eur Econ Rev 2002;46:1475-500.

[37] Painuly JP. Barriers to renewable energy penetration; a framework for analysis. Renew Energy 2001;24:73-89. doi:https://doi.org/10.1016/S0960-1481(00)00186-5.

[38] Putri IA. Causes Of Corruption Behaviour On The Case Of Marked Up Prices In The Land Acquisition For Construction Of Pln Office Building Th Rayon Kuranji 2007 In Padang City. In: Prof. dr. Agus Suwandono MDP, Kamil PDS, Pheni Chalid, SE., MA. P hD., Dr. Irwansyah M, Dr. Jamin Ginting, SH. M, Ries Wulandari MS, editors. Role Educ. Students Build. Integr., Jakarta, Indonesia: Tiri -Integrity Action; 2013.

[39] Aneta, Yanti; Akib, Haedar; Kadji, Yulianto; Basri M. Organizational transformation: the revitalization of the role and function for human resources (case study of PT. PLN Area Gorontalo). Int J Acad Res 2014;6.

[40] MEMR. Buku Potensi Panas Bumi. Jakarta, Indonesia: 2017.

[41] Pambudi NA. Geothermal power generation in Indonesia, a country within the ring of fire: Current status, future development and policy. Renew Sustain Energy Rev 2018;81:2893-901. doi:10.1016/j.rser.2017.06.096.

[42] Muharti A. Government/ World Bank \$275m geothermal fund to push development in Indonesia. Migas Rev 2017.

[43] Erinofiardi, Gokhale P, Date A, Akbarzadeh A, Bismantolo P, Suryono AF, et al. A Review on Micro Hydropower in Indonesia. Energy Procedia 2017;110:316-21. doi:https://doi.org/10.1016/j.egypro.2017.03.146.

[44] Pirard R, Bär S, Dermawan A. Challenges and opportunities of bioenergy development in Indonesia 2016.

[45] IESR Indonesia. Potensi dan Peran Photovoltaic dan PV Rooftop untuk Mempercepat EBT. Jakarta, Indonesia: 2017.

[46] Mahmudah AA. Double Turbine Wave Energy: Inovasi Pembangkit Listrik Tenaga Gelombang Laut. Bandung: 2017.

[47] Halimanjaya A, McFarland W. Survival of climate action under new president. Jakarta Post 2014.

[48] MOF. Jaringan dokumentasi dan informasi hukum Kementerian Keuangan RI 2017. http://www.sjdih.depkeu.go.id/Ind/ (accessed December 26, 2017).

[49] MEMR. Jaringan dokumentasi dan informasi hukum Kementerian Energi dan Sumber Daya Mineral 2017. http://jdih.esdm.go.id/?page=home (accessed December 26, 2017).

[50] Fritz V, Kaiser K, Levy B. Problem-Driven Governance and Political economy Analysis. Washington D. C.: 2009.
[51] Cronin P, Ryan F, Coughlan M. Undertaking a literature review: a step-by-step approach. Br J Nurs 2008;17:38.

[52] Bridle R, Gass P, Halimajaya A, Lontoh L, McCulloch N, Petrofsky E, et al. Missing the 23 Per Cent Target: Roadblocks to the Development of Renewable Energy in Indonesia. 2018.

[53] Raha T. Tarif Listrik PLTBm dan PLTBg Akan Gunakan Dolar. Migas Rev 2015.

[54] MOI. Agenda penting kemenperin: kebijakan industri nasional. Kementeri Perindustrian 2018. http://www.kemenperin.go.id/artikel/19/Kebijakan-IndustriNasional (accessed January 3, 2018).

[55] The Jakarta Post. EDITORIAL: Funding geothermal exploration. Jakarta Post 2017.

[56] MEMR. ESDM: Perbaikan Pelayanan 2017. https://www.esdm.go.id/id/bureaucratic-reform/public-serviceinnovation-/service-improvement- (accessed December 27, 2017).

[57] GOI. Undang-undang No. 30 Tahun 2009 Tentang Ketenagalistrikan. Indonesia: 2009.

[58] Mahkamah Konstitusi. Constitutional Court Decision No. 111/PUU-XIII/2015. Indonesia: 2015.

[59] Halimanjaya A, Maulidia M. The coordination of climate finance in Indonesia. London: 2014.

[60] McCulloch L. Trifungsi: The Role of the Indonesian Military in Business. In: Brömmelhörster J, Paes W-C, editors. Mil. as an Econ. Actor Soldiers Bus., London: Palgrave Macmillan UK; 2003, p. 94-123. doi:10.1057/9781403944009_6.

[61] Metrotvnews. Perlu Orang Militer Jadi Petinggi di Perusahaan BUMN 2016.

[62] Halimanjaya A, Saputro E. Tackling climate change needs ministry coordination. Jakarta Post 2015.

[63] Martens B, Mummert U, Murrell P, Seabright P. The institutional economics of foreign aid 2002.

[64] Pratiwi I. PLN Lakukan Koordinasi dengan Kementerian BUMN dan ESDM. Http://www.republika.co.id/ 2017.

[65] Republic of Indonesia. First Nationally Determined Contribution: Republic of Indonesia. Jakarta, Indonesia: 2016.

[66] Hix S. The Political System of the European Union. 2nd ed. New York: Palagrave Macmillan; 2005.

[67] Ihsanuddin. Ada Empat Kementerian yanga Akan Berada di Bawah Kemenko Maritim. Kompas.com 2014.

[68] Jefriando M. Utang PLN Membahayakan Keuangan Negara. DetikFinance 2017.

[69] Ansuategi A, Escapa M. Economic growth and greenhouse gas emissions. Ecol Econ 2002;40:23-37. doi:10.1016/s09218009(01)00272-5.

[70] Hadiat T. Proses Pengadaan dan Standar Kontrak Pembangkit Tenaga Listrik Yang Memanfaatkan Sumber Energi Terbarukan 2017. 